\title{
Nitrogen budgets of urban lawns under three different management regimes in southern California
}

\author{
Wenwen Wang • Darren Haver • Diane E. Pataki
}

Received: 22 July 2013/ Accepted: 15 December 2013/Published online: 29 December 2013

(C) The Author(s) 2013. This article is published with open access at Springerlink.com

\begin{abstract}
We constructed nitrogen (N) budgets for the lawns of three simulated residences built to test the environmental impacts of three different residential landscape designs in southern California. The three designs included: a "Typical" lawn planted with cool season tall fescue (Schedonorus phoenix), fertilized at the recommended rate for this species $\left(192 \mathrm{~kg}^{-1} \mathrm{ha}^{-1}\right.$ year $^{-1}$ ) and irrigated with an automatic timer; a design intended to lower $\mathrm{N}$ and water requirements ("Low Input") with the warm season seashore paspalum (Paspalum vaginatum) fertilized at $123 \mathrm{~kg}^{-1} \mathrm{ha}^{-1}$ year $^{-1}$ and irrigated with a soil moisture-based system; and a design incorporating local best practices ("Low Impact" lawn) that included the native sedge species Carex, fertilized at $48 \mathrm{~kg}^{-1} \mathrm{ha}^{-1}$ year ${ }^{-1}$ and irrigated by a weather station-based system. Plant $\mathrm{N}$ uptake accounted for $33.2 \pm 0.5$ (tall fescue), $53.7 \pm 0.7$ (seashore paspalum), and $12.2 \pm 1.3 \%$ (Carex) of
\end{abstract}

Responsible Editor: Sujay Kaushal.

W. Wang

Department of Ecology \& Evolutionary Biology,

University of California, Irvine, CA 92697, USA

D. Haver

University of California Cooperative Extension, 1045

Arlington Drive, Costa Mesa, CA 92626, USA

D. E. Pataki $(\square)$

Department of Biology, University of Utah, Salt Lake

City, UT 84112, USA

e-mail: diane.pataki@utah.edu annual $\mathrm{N}$ inputs, while estimated $\mathrm{N}$ retention in soil was relatively large and similar in the three lawns (41-46\%). At lower $\mathrm{N}$ and water inputs than Typical, Low Input showed the highest annual clipping yield and $\mathrm{N}$ uptake, although it also had higher denitrification rates. Leaching inorganic $\mathrm{N}$ losses remained low even from the Typical lawn (2\%), while gaseous $\mathrm{N}$ losses were highly variable. The Low Input lawn was most efficient in retaining $\mathrm{N}$ with relatively low water and $\mathrm{N}$ costs, although its fertilization rates could be further reduced to lower gaseous $\mathrm{N}$ losses. Our results suggest that the choice of a warm-season, $\mathrm{C}_{4}$ turf species with reduced rates of irrigation and fertilization is effective in this semi-arid region to maintain high productivity and $\mathrm{N}$ retention in plants and soils at low $\mathrm{N}$ and water inputs.

Keywords Turfgrass - Lawns - N cycling · Urban biogeochemistry

\section{Introduction}

$\mathrm{N}$ biogeochemistry of urban ecosystems has likely been greatly altered by intensive inputs of reactive $\mathrm{N}$ from fossil fuel burning and $\mathrm{N}$ fertilizer application (Galloway et al. 2003). However, urban ecosystems are less studied and relatively poorly understood compared to natural ecosystems. Urban lawns, which are usually heavily fertilized (Law et al. 2004), are an important component of urban landscapes and are estimated to occupy $1.9 \%$ of the total area of the U.S 
and 40-60 \% of the area estimated to be under urban development (Milesi et al. 2005). Management practices can strongly affect plant and soil $\mathrm{N}$ dynamics in urban lawns. As urban areas continue to expand, there is a great need for datasets that can be used to develop and test theories about $\mathrm{N}$ biogeochemistry of managed lawns within urban ecosystems.

Relieved from limitations of $\mathrm{N}$ and water and not as regularly tilled as croplands, urban lawns can accumulate soil organic carbon (SOC) and $\mathrm{N}$ at similar or even greater rates than natural grasslands and forests (Huh et al. 2008; Qian and Follett 2002; Pataki et al. 2006; Pouyat et al. 2003, 2006; Raciti et al. 2011a). Therefore, it is important to study the $\mathrm{N}$ biogeochemistry of fertilized urban lawns within the context of global change. ${ }^{15} \mathrm{~N}$-tracer studies have shown that mineral soil and plant biomass are usually the primary sinks for fertilizer N in lawns (Engelsjord et al. 2004; Frank et al. 2006; Horgan et al. 2002a, b; Raciti et al. 2008). Raciti et al. (2008) and Frank et al. (2006) similarly reported a peak recovery of ${ }^{15} \mathrm{~N}$-labeled fertilizer in plant biomass within a short period (days), while soils dominated the long-term ${ }^{15} \mathrm{~N}$ recovery ( $\geq 1$ year) in urban lawns. However, a large portion of ${ }^{15} \mathrm{~N}$ could remain in clipping biomass, if such clippings were removed from the lawns instead of being left on site (Engelsjord et al. 2004; Horgan et al. 2002a, b).

Fertilizer $\mathrm{N}$ that exceeds plant needs and soil capacity may leave lawns in various ways, while the potential of high $\mathrm{N}$ losses in response to overfertilization may increase with lawn age (Frank et al. 2006). Excessive $\mathrm{N}$ inputs to lawns may enter groundwater as ammonium $\left(\mathrm{NH}_{4}{ }^{+}\right)$and nitrate $\left(\mathrm{NO}_{3}{ }^{-}\right.$, Jiao et al. 2004; Petrovic 1990) through leaching, causing threats to public health (Scanlon et al. 2007), or enter the atmosphere through ammonia $\left(\mathrm{NH}_{3}\right)$ volatilization (Torello et al. 1983) and emissions of nitrous oxide $\left(\mathrm{N}_{2} \mathrm{O}\right)$ and nitrogen monoxide $(\mathrm{NO})$ in nitrification and denitrification (Bouwman et al. 2002; Clayton et al. 1997; Eichner 1990; Firestone and Davison 1989; Townsend-Small et al. 2011). Kaye et al. (2004) showed that urban lawns occupied $6.4 \%$ of their study region of urban soils (including urban impervious, urban lawns, agricultural land, and native grassland) but contributed $30 \%$ of the regional emissions of $\mathrm{N}_{2} \mathrm{O}$, which is a powerful greenhouse gas (IPCC 2001).

Lawn irrigation is another concern with regard to both landscape water use and soil $\mathrm{N}$ losses. Lawns are the largest irrigated crop in the U.S. (Milesi et al.
2005), and receive approximately $70 \%$ of the water used in landscape irrigation in California (Gleick et al. 2003). Increases in soil moisture may significantly accelerate soil $\mathrm{N}$ cycling in arid/semi-arid ecosystems (Wang and Pataki 2012), while a combination of high soil $\mathrm{N}$ availability and high soil moisture levels in managed lawns could lead to considerable drainage and $\mathrm{N}$ leaching (Morton et al. 1988) as well as high $\mathrm{N}_{2} \mathrm{O}$ emissions, especially at warm temperatures (Bijoor 2008). "Smart" irrigation controllers can reduce water use by automatically adjusting water application based on soil moisture or weather conditions (Davis et al. 2009; Devitt et al. 2008a; McCready et al. 2009). However, relatively few studies have examined lawn plant and soil $\mathrm{N}$ dynamics other than leaching losses in response to irrigation (Morton et al. 1988; Pathan et al. 2007; Synder et al. 1984).

Finally, the choice of turfgrass species could modify the seasonality and magnitudes of plant $\mathrm{N}$ uptake and soil $\mathrm{N}$ losses. In general, plant urease activities and root uptake of $\mathrm{N}$ and water can affect the magnitudes of $\mathrm{NH}_{3}$ volatilization (Frankenberger and Tabatabai 1982), N leaching (Bowman et al. 2002; Crush et al. 2005), and denitrification (Virginia et al. 1982). $\mathrm{C}_{4}$, warm-season turf species are known for low water requirements (Huang et al. 1997; Youngner et al. 1981). In semi-arid urban ecosystems, these species may be associated with reduced water and $\mathrm{N}$ inputs and smaller ecosystem $\mathrm{N}$ losses relative to $\mathrm{C}_{3}$, cool-season species because of higher productivity and high efficiencies in $\mathrm{N}$ and water use under warm temperatures (Long 1999). However, there have been few studies comparing the performance of $\mathrm{C}_{3}$ and $\mathrm{C}_{4}$ turf species with regard to their efficiency in $\mathrm{N}$ retention under their recommended management regimes.

In this study, we measured $\mathrm{N}$ dynamics and constructed $\mathrm{N}$ budgets of the lawn portions of three simulated residences designed to test the environmental performance of common versus recommended residential landscape designs in southern California. The residences differed in the design and management regimes of the lawn portions of the yards: one was designed to represent typical landscape design and management practices in southern California ("Typical"), including the use of a $\mathrm{C}_{3}$ fescue species and automated irrigation timers; the second utilized recommendations for retrofitting landscapes to reduce $\mathrm{N}$ and water inputs ("Low Input") with a C4 turf species and a soil moisture-based irrigation system; and the 
third was a "state-of-the-art" design intended to maximize water and N conservation ("Low Impact") with a native sedge lawn and a weather stationcontrolled irrigation system. Each lawn was fertilized according to the recommendations of the University of California Cooperative Extension.

We conducted a suite of measurements to construct relatively complete $\mathrm{N}$ budgets for each of these lawns, including: major $\mathrm{N}$ inputs (fertilizer application, atmospheric $\mathrm{N}$ deposition, and irrigation water); gaseous $\left(\mathrm{NH}_{3}, \mathrm{~N}_{2}, \mathrm{~N}_{2} \mathrm{O}\right.$, and $\left.\mathrm{NO}\right)$ and leaching losses of inorganic $\mathrm{N}\left(\mathrm{NH}_{4}{ }^{+}\right.$and $\left.\mathrm{NO}_{3}{ }^{-}\right)$; $\mathrm{N}$ outputs in removed plant clippings; the residual $\mathrm{N}$ fluxes, and potential changes in $\mathrm{N}$ stocks in soil. We constructed $\mathrm{N}$ budgets at two time scales: a 30-day scale following fertilizer application and the annual scale. Our specific hypotheses were: (1) plant clippings and $0-10 \mathrm{~cm}$ mineral soil would be the primary $\mathrm{N}$ sinks in all three lawns, as suggested by previous ${ }^{15} \mathrm{~N}$ studies; (2) the productivity and $\mathrm{N}$ uptake of the $\mathrm{C}_{4}$ turf species would be higher than the $\mathrm{C}_{3}$ species in warmer seasons even at much lower rates of fertilization and irrigation; (3) gaseous and aqueous $\mathrm{N}$ losses would be important fluxes in the Typical lawn, which received the highest rates of fertilization and irrigation, but relatively minor fluxes in Low Input and Low Impact. By testing the performance of these three landscape designs and their management practices, we sought to improve our understanding of urban lawn biogeochemistry and the best management practices for reducing $\mathrm{N}$ losses from fertilized ecosystems.

\section{Materials and methods}

Study site and climatic data

This study was conducted at a research facility at the South Coast Research and Extension Center in Irvine, Orange County, California $\left(33^{\circ} 41^{\prime} 20.16^{\prime \prime} \mathrm{N}\right.$, $117^{\circ} 43^{\prime} 24.26^{\prime \prime} \mathrm{W}, 123 \mathrm{~m}$ above mean sea level, Mediterranean climate). The simulated residences consisted of model houses complete with driveways, curb and gutter, and both front and backyards designed and managed to simulate typical versus recommended practices for southern California (Photo 1). The experiment was designed and operated by the University of California Cooperative Extension of Orange County, and reflects their local
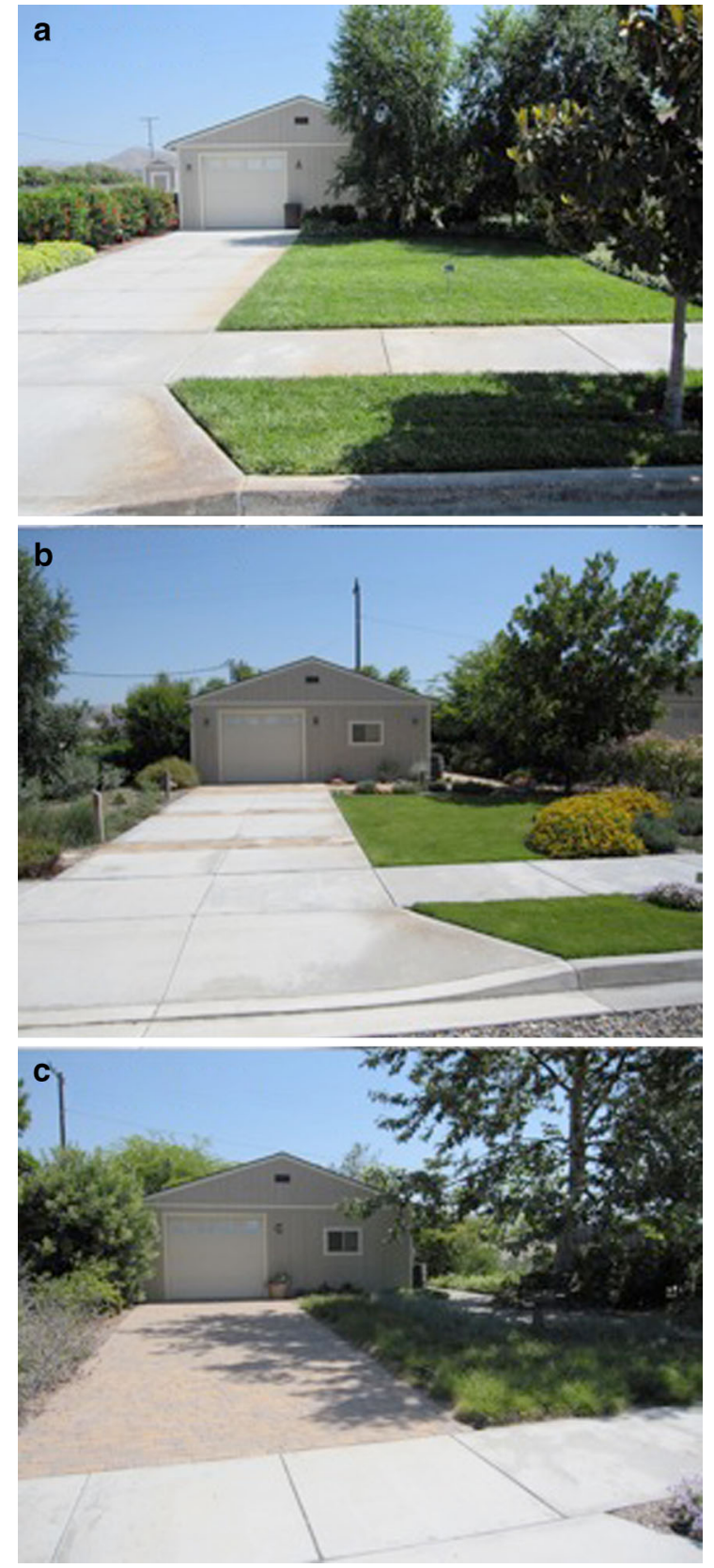

Photo 1 Photos of the three simulated residences in 2010 (a Typical, b Low Input, and c Low Impact). Lawns are planted in both front and back yards

expertise in assessing both common and best management practices for local landscapes (http:// ceorange.ucdavis.edu/). The goals of the study were to facilitate complete instrumentation of water and $\mathrm{N}$ budgets and surface runoff from both pervious and impervious surfaces of Orange County 
residential parcels, using methods that are usually too intrusive for studies of actual residences.

This study focused on the lawn portions of the landscapes, though each contained other vegetation types and either pervious or impervious surfaces surrounding the lawns, as the study incorporated complete, parcel-scale landscape designs. Hence, the sizes of the lawns varied by landscape. The lawns in the Typical landscape $\left(129 \mathrm{~m}^{2}\right)$ and the Low Input landscape $\left(43 \mathrm{~m}^{2}\right)$ were both established in September 2006 by placing pallets of sods on a layer $(5-7.5 \mathrm{~cm})$ of biosolids (compost, the Biosolid Program of Orange County Sanitation District, or OCSD) on top of local soil. The typical lawn consisted of tall fescue (Schedonorus phoenix, a cool-season, $\mathrm{C}_{3}$ species formerly known as Festuca arundinacea) and was established from Marathon II sod (Southland Sod Farms, Oxnard, CA, USA) with a $6.3-7.5 \mathrm{~cm}$ root/soil base (sod soil N\%: $0.06 \pm 0.002 \%)$,. The Low Input lawn consisted of seashore Paspalum (Paspalum vaginatum, a $\mathrm{C}_{4}$ species) established from Sea Spray sod (West Coast Turf, Winchester, CA, USA) with a $5 \mathrm{~cm}$ root/soil base (sod soil N\%:0.11 $\pm 0.01 \%$ ). The Low Impact lawn $\left(54 \mathrm{~m}^{2}\right)$ was established in January 2007 with plugs of the cool-season, $\mathrm{C}_{3}$, California native sedge Carex (Euro American Propagators, Bonsall, CA, USA) grown in a layer of 1.3-2.5 cm OCSD biosolids on local soil. The total N\% of OSCD biosolids was $1.4 \%$ (Soil Control lab, 2007), while the local soil originally had an organic matter content of $0.42 \pm 0.17 \%$, and a texture of $79.2 \pm 2.9 \%$ sand, $9.4 \pm 1.3 \%$ silt, and $11.4 \pm 1.7 \%$ clay (UC Davis Analytical Laboratory, 2005).

The lawn in the Typical landscape was irrigated on a regular schedule (3 days per week, 12 min per time) with an automated timer (Rain Bird 4 Station ESP Modular Series Controller, Rain Bird, Azusa, CA, USA, Hartin and Harivandi 2001) and fertilized at $192 \mathrm{~kg} \mathrm{~N} \mathrm{ha}^{-1}$ year $^{-1}$ in four equal applications, as is recommended for this lawn type (Henry et al. 2002). The fertilizer was Scotts ${ }^{\circledR}$ Turf Builder ${ }^{\circledR}$ 29-2-4 (Scotts Miracle-Gro, Marysville, OH, USA) in 2010 and Schultz ${ }^{\circledR}$ super 21-0-0 (United Industries Cooperation, St. Louis, MO, USA) in 2011, both of which are mainly urea/coated urea. During our study, there were 6 fertilization events on March 29, May 24, August 16, and September 21 in 2010 and March 8 and May 16 in
2011. The Low Input lawn was irrigated by an automated system utilizing soil moisture sensors (Watermark Electronic Module, Irrometer, Riverside, CA, USA) which triggers at low soil moisture levels ( $\sim 25 \mathrm{kPa}$ at $25 \mathrm{~cm}$ depth) and fertilized with the same fertilizer and schedule as Typical, but at only half the rate, consistent with recommendations $\left(25 \mathrm{~kg} \mathrm{~N}^{-1}\right.$ application $^{-1}$, Henry et al. 2002). However, there was a one-time application of doubled rate at $48 \mathrm{~kg} \mathrm{~N}^{-1}$ on August 16, 2010 to maintain visual quality, resulting in a total rate of $123 \mathrm{~kg} \mathrm{~N} \mathrm{ha}^{-1}$ year $^{-1}$ in 2010, and the first fertilization in 2011 was on March 29 instead of March 8. The lawn in the Low Impact landscape was irrigated by a weather-based Hunter ET System connected to a Hunter ICC irrigation controller (Hunter, San Marcos, CA, USA) that adjusts water application according to crop evapotranspiration (ET) rates calculated with onsite weather observations in a modified version of the Penman equation (Pruitt and Doorenbos 1977; Snyder and Pruitt 1985) and cropspecific coefficients by the California Irrigation Management Information System (CIMIS, www.cimis. water.ca.gov). The Low Impact Lawn was not fertilized before 2010, but was fertilized on March 29, 2010 and March 8, 2011 at $48 \mathrm{~kg} \mathrm{~N} \mathrm{ha}^{-1}$ year $^{-1}$ with Vigoro ${ }^{\circledR}$ Ornamental 8-4-8 Plus Minors (Vigoro Corp., Chicago, MI, USA). Following each fertilizer application, the fertilized lawns were irrigated for about 2 min. The Typical lawn and Low Input lawn were mowed regularly during the growing season once a week or every other week to a height of 7.6 and $2.5 \mathrm{~cm}$, respectively, while the Low Impact lawn was only mowed once a year to the height of $2.5 \mathrm{~cm}$. The clippings from all lawns were directly captured by mower and removed from the lawns.

Three time-domain reflectometers (CS616, Campbell Scientific, Inc., Logan, UT, USA) were installed in each lawn in 2008 to measure soil moisture. The installation depth was $15 \mathrm{~cm}$ for Typical, $20 \mathrm{~cm}$ for Low Input, and $25 \mathrm{~cm}$ for Low Impact, to correspond to rooting depth. The sensors were logged (CR10X, Campbell Scientific, Inc., Logan, UT, USA) every $30 \mathrm{~s}$ and averaged every $30 \mathrm{~min}$. Climatic data, such as air temperature, soil temperature, and precipitation, were obtained from a CIMIS network station which was located at the site (Irvine station, \#75, http://www. cimis.water.ca.gov). 
$\mathrm{N}$ inputs from atmospheric deposition and irrigation water

The total $\mathrm{N}$ inputs $\left(\mathrm{N}_{\text {total }} \pm \mathrm{SE}_{\mathrm{t}}\right)$ were calculated as

$N_{\text {total }}=N_{\text {fert }}+N_{\text {atm }}+N_{\text {irr }}$

$S E_{t}=\sqrt{S E_{a t m}^{2}+S E_{i r r}^{2}}$

where $\mathrm{N}_{\text {fert }}, \mathrm{N}_{\mathrm{atm}}$, and $\mathrm{N}_{\mathrm{irr}}$ are $\mathrm{N}$ inputs from fertilizer application, atmospheric $\mathrm{N}$ deposition, and irrigation water, respectively. $\mathrm{N}_{\mathrm{atm}}$ and $\mathrm{N}_{\mathrm{irr}}$ were estimated as

$N_{a t m}=N_{d r y}+N_{w e t}$

$N_{\text {irr }}=I N_{\text {irr }} * V_{\text {irr }}$

where $\mathrm{N}_{\text {dry }}$ and $\mathrm{N}_{\text {wet }}$ are atmospheric dry and wet deposition, and $\mathrm{IN}_{\text {irr }}$ and $\mathrm{V}_{\text {irr }}$ are the average $\mathrm{IN}$ concentrations of irrigation water and irrigation volume, respectively.

$\mathrm{N}_{\text {wet }}$ during the rainy winter seasons was measured with ion exchange resin (IER) collectors based on the design by Fenn and Poth (2004), which can last 3-12 months as needed. Five IER collectors were installed in the open area around the study site on December 12, 2010 and collected on July 21, 2011. Briefly, an IER column was attached to the bottom of a dark-colored funnel with $20-\mathrm{cm}$ diameter and $10-\mathrm{cm}$ vertical side walls, and was mounted at $2 \mathrm{~m}$ above the ground. The IER was Amberlite IRN 150 Mixed Bed IER (Amberlite ${ }^{\mathrm{TM}}$ IRN 77 + Amberlite $^{\mathrm{TM}}$ IRN78), with polyester fibers in both ends to prevent particles from entering. After removal, the IER columns were sent to the Forest Fire Laboratory, US Forest Service Pacific Southwest Station (Riverside, CA. USA), where the IER was extracted with $2 \mathrm{M}$ potassium chloride $(\mathrm{KCl})$ and analyzed for inorganic $\mathrm{N}\left(\mathrm{NH}_{4}{ }^{+}-\mathrm{N}\right.$ and $\mathrm{NO}_{3}{ }^{-}-\mathrm{N}$ ) concentrations colorimetrically with an TRAACS 800 Autoanalyzer (Tarrytown, NY, USA, Fenn et al. 2006). Although we used a coarse mesh screen to prevent material from entering the funnel, litter contamination was still severe, leaving only one usable sample for $\mathrm{NH}_{4}{ }^{+}-\mathrm{N}$; the $\mathrm{NO}_{3}{ }^{-}-\mathrm{N}$ data were not affected. $\mathrm{N}_{\mathrm{dry}}$, which is usually the largest component of $\mathrm{N}$ deposition in California and could be 10 times higher than $\mathrm{N}_{\text {wet }}$ (Bytnerowicz and Fenn 1996; Fenn et al. 2003), was not directly measured in our study. According to Fenn et al. (2010), the atmospheric dry deposition in central Orange County ranged from 9 to $15 \mathrm{~kg} \mathrm{~N} \mathrm{ha}^{-1}$ year $^{-1}$, so we applied a value of $12 \mathrm{~kg} \mathrm{~N} \mathrm{ha}^{-1}$ year $^{-1}$ for our $\mathrm{N}$ budgets. Our method may tend to slightly over-estimate the atmospheric $\mathrm{N}$ deposition as the IER results might overlap with part of the dry deposition.

$\mathrm{V}_{\text {irr }}$ was monitored on a weekly basis using five randomly placed cups, with $5 \mathrm{ml}$ mineral oil added to each to prevent evaporation from June 232010 to May 29 2011. Irrigation water was sampled directly from the irrigation valve onsite in January, March, June, October, and December 2010 and stored at $4{ }^{\circ} \mathrm{C}$ until analyzed colorimetrically for $\mathrm{NH}_{4}{ }^{+}-\mathrm{N}$ and $\mathrm{NO}_{3}{ }^{-}-\mathrm{N}$ concentrations using the phenol-hypochlorite method by Weatherburn (1967) and the vanadium method by Doane and Horwath (2003). $\mathrm{IN}_{\text {irr }}$ was calculated as the average of the IN concentrations of the five samples.

$\mathrm{N}$ output in plant clippings

The biomass $\mathrm{N}$ in plant clippings at 30-day $\left(\mathrm{N}_{\text {clip_30 }} \pm \mathrm{SE}_{i}\right)$ or annual $\left(\mathrm{N}_{\text {clip_365 }} \pm \mathrm{SE}_{\mathrm{p}}\right)$ scales was calculated as

$N_{\text {clip_30 }}=$ biomass $*$ biomass $\% N$

$N_{\text {clip_365 }}=\sum_{i=1}^{n}\left(\right.$ biomass $_{i} *$ biomass $\left.\% N_{i}\right)$

$S E p=\sqrt{\sum_{i=1}^{n} S E_{i}^{2}}$

where $n$ is the number of mowing events in 2010 for each lawn. Equations are only shown for errors (SE) that were propagated from other errors, i.e., $\mathrm{SE}_{\mathrm{p}}$, but not for those directly calculated from samples, i.e., $\mathrm{SE}_{i}$.

There were 36 and 32 mowing events for Typical and Low Input, respectively, while Low Impact was only mowed once a year. All plant clippings were collected, oven dried at $70{ }^{\circ} \mathrm{C}$ for 1 week (extended drying time due to the large quantities of clippings), and weighed. Clippings were sub-sampled at intervals throughout for analysis of N\% from Typical $(n=17)$ and Low Input $(n=13)$. Three random portions of plant clippings were weighed $(\sim 10 \mathrm{~g})$ from each subsample, homogenized, and ground to fine power for analysis on an elemental analyzer (EA, Fisons NA1500 NC, San Carlos, CA, USA) coupled to an Isotope Ratio Mass Spectrometer (Delta Plus IRMS, Thermofinnigan, San Jose, CA, USA). N output in plant clippings within 30 days following each fertilization event in the 
Typical and Low Input lawns was calculated as the product of the clipping biomass and $\mathrm{N} \%$ during that time period. At the annual scale, clipping biomass $\mathrm{N}$ for each of the three lawns was estimated as the sum of biomass $\mathrm{N}$ from all mowing events. We did not measure the aboveground biomass that remained after mowing (verdure), since it was always left at similar height and not likely to vary very much in $\mathrm{N}$ stocks (Engelsjord et al. 2004; Frank et al. 2006).

$\mathrm{N}$ outputs in gaseous and aqueous forms

Gaseous $\mathrm{N}$ fluxes at 30 day $\left(\mathrm{N}_{\text {gas_30 }} \pm \mathrm{SE}_{g 30}\right)$ and annual $\left(\mathrm{N}_{\text {gas_365 }} \pm \mathrm{SE}_{g 365}\right)$ scales were estimated as

$N_{\text {gas_30 }}=\sum_{i=1}^{k} a_{i}+\sum_{j=1}^{30-k} b$

$S E_{g 30}=\sqrt{\sum_{i=1}^{k} S E_{i}^{2}+\left((30-k) * S E_{b}\right)^{2}}$

$N_{\text {gas_365 }}=\sum_{i=1}^{m} N_{\text {gas } \_30 i}+\sum_{j=1}^{30 * n} b$

$S E_{g 365}=\sqrt{\sum_{i=1}^{m} S E_{g 30 i}^{2}+\left(30 * n * S E_{b}\right)^{2}}$

where $\mathrm{a}_{i} \pm \mathrm{SE}_{i}$ represents the average daily fluxes of gaseous $\mathrm{N}$ following fertilization and $\mathrm{b} \pm \mathrm{SE}_{b}$ is the background flux estimated based on pre-fertilization sampling; $\mathrm{k}, \mathrm{m}$, and $\mathrm{n}$ represent the number of sampling days following fertilization, the number of months with fertilization, and the number of months without fertilization ( $m=4, n=8$ for Typical and Low Input, $m=1, n=11$ for Low Impact), respectively.

We measured $\mathrm{NH}_{3}$ volatilization following fertilization with four open containers, each with $40 \mathrm{ml}$ $2 \%$ (v:v) sulfuric acid $\left(\mathrm{H}_{2} \mathrm{SO}_{4}\right)$, randomly placed on each lawn and tightly covered with PVC chambers (diameter $=25 \mathrm{~cm}$ ) for $24 \mathrm{~h}$, after which the solution was collected and stored at $4{ }^{\circ} \mathrm{C}$ for IN analysis. Daily $\mathrm{NH}_{3}$ volatilization from the lawn was calculated as the increase in $\mathrm{NH}_{4}{ }^{+}-\mathrm{N}$ in the solution per unit chamber area per day (Schlesinger and Peterjohn 1991). This procedure was repeated in each lawn following every fertilization event for up to 7 days, except that Low Impact was only measured following its single fertilization event in 2011. Pre-fertilization sampling was conducted 1 day before each of the 6 fertilization events in every lawn. Background $\mathrm{NH}_{3}$ fluxes from each lawn were estimated as the average of all 6 prefertilization sampling events.

$\mathrm{N}_{2} \mathrm{O}$ fluxes were measured using static PVC chambers $(n=4$, diameter $=25 \mathrm{~cm}$, TownsendSmall and Czimczik 2010; Townsend-Small et al. 2011) randomly placed on each lawn the day before fertilization and on a daily basis following each of the 6 fertilization events (early morning) for 5-7 days. Air samples were removed from the chamber using $30 \mathrm{ml}$ nylon syringes at $0,7,14,21$, and $28 \mathrm{~min}$, injected into air-tight, pre-evacuated headspace vials, and analyzed within $24 \mathrm{~h}$ on a gas chromatograph (GC) fitted with an electron capture detector (GC-2014 Nitrous Oxide Analyzer, Shimadzu Scientific Instruments). $\mathrm{N}_{2} \mathrm{O}$ fluxes were calculated from the slope of the fitted regression line of $\mathrm{N}_{2} \mathrm{O}$ concentrations versus time in each chamber. Fluxes were considered undetectable, i.e., zero, if $\mathrm{R}^{2}<0.9$. Volumetric soil water content $(0-5 \mathrm{~cm})$ was measured beneath each chamber immediately following sampling using a portable soil moisture meter (TH2O, Dynamax, Inc, Houston, TX, USA). NO fluxes were not directly measured; however, we estimated a range based on the two extremes of the reported $\mathrm{NO} / \mathrm{N}_{2} \mathrm{O}$ ratios from field measurements or model simulation of lawns or fields fertilized with urea (0.005-14.7, Gu et al. 2009; Hall et al. 2008; Parton et al. 2001; Stehfest and Bouwman 2006; Williams et al. 1998). As a comparison, NO fluxes were also estimated as 1-3\% of nitrification (Baumgartner and Conrad 1992; Hutchinson and Davidson 1993) based on the net nitrification rates of each lawn.

To measure denitrification rates, four soil cores $(0-10 \mathrm{~cm})$, one from under each of the four PVC chambers, were extracted following the removal of chambers after each $\mathrm{N}_{2} \mathrm{O}$ sampling event and transferred to the lab immediately for denitrification analysis using the acetylene-blocking technique (Drury et al. 2008). An additional soil core was taken from the lawns in March and May 2011 in order to increase the sample size ( $n=5$ in total). To minimize damage to the lawns, cores were only $1.5 \mathrm{~cm}$ in diameter. Acetylene gas was used to block denitrification pathways and convert all denitrification products to $\mathrm{N}_{2} \mathrm{O}$. Chambers were constructed from $8 \mathrm{oz}$ mason jars with two syringe stopcocks installed in the lid. Each soil core was placed in a chamber and flushed 
with $\mathrm{N}_{2}$ for $5 \mathrm{~min}$. At time $0,15,30,45$, and $60 \mathrm{~min}$, air samples were removed with a $30 \mathrm{ml}$ nylon syringe, and acetylene gas was injected. $\mathrm{N}_{2} \mathrm{O}$ concentrations in the air samples were analyzed and calculated in the same way as in situ air samples from the lawns. After the acetylene-blocking test, the soil cores were sieved at $2 \mathrm{~mm}$, oven dried at $110{ }^{\circ} \mathrm{C}$ for $48 \mathrm{~h}$, and weighed. The denitrification rates of the soil cores were estimated from the $\mathrm{N}_{2} \mathrm{O}$ fluxes over time per unit of dry soil. Measurements were conducted on a daily basis up to 7 days. Pre-fertilization sampling was conducted 1 day before each of the 6 fertilization events in every lawn. Background denitrification rates in each lawn were estimated as the average of all 6 prefertilization sampling events.

To assess the leaching IN concentrations, three lysimeters with ceramic tips (Irrometer ${ }^{\circledR}$ Soil Solution Access Tubes, Riverside, CA, USA) were installed in summer 2010 at $40 \mathrm{~cm}$, below the rooting zone $(0-10 \mathrm{~cm})$. Soil solution samples were extracted every day following fertilization for up to 5 days in March 2011 from Low Impact and following fertilization in the other two lawns in August 2010, September 2010, March 2011, and May 2011. Pre-fertilization sampling was conducted in every lawn before each fertilization event. Each lysimeter was evacuated with an air pump for $60 \mathrm{~s}$ and left overnight in the soil to allow soil solution to flow into the tube through the ceramic tip; soil solution samples were extracted with a $60 \mathrm{ml}$ nylon syringe on the second day. All samples were filtered with $0.2 \mu \mathrm{m}$ microfilters, stored at $4{ }^{\circ} \mathrm{C}$ until analyzed colorimetrically for $\mathrm{NH}_{4}{ }^{+}-\mathrm{N}$ and $\mathrm{NO}_{3}{ }^{-}-\mathrm{N}$ using the phenol-hypochlorite method by Weatherburn (1967) and the vanadium method by Doane and Horwath (2003). Due to varying soil moisture conditions, we were not always able to collect all three samples. Drainage was estimated with the simplified equation:

$D=I+P-R-E T_{0}$

where $\mathrm{D}, \mathrm{I}, \mathrm{P}$, and $\mathrm{R}$ represents drainage, irrigation, precipitation, and runoff, respectively. Daily precipitation and $\mathrm{ET}_{0}$ rates were obtained from the CIMIS network station nearby (Irvine station, \#75, http:// www.cimis.water.ca.gov). Runoff was measured by collecting all surface runoff in $0.3 \times 0.3 \mathrm{~m}$ concrete vaults downslope of each landscape. Electronic water sensing sump pumps (Water Ace, Ashland, OH, USA) transported runoff through an oscillating piston type water meter pulse flow meter (C700, Elster AMCO
Water, Langley, Canada) which was logged daily (CR1000, Campbell Scientific, Inc., Logan, UT, USA).

The leaching inorganic $\mathrm{N}$ fluxes at 30 day $\left(\mathrm{N}_{\text {leach_30 }} \pm \mathrm{SE}_{l 30}\right)$ and annual $\left(\mathrm{N}_{\text {leach_365 }} \pm \mathrm{SE}_{l 365}\right)$ scales were estimated as

$$
\begin{aligned}
& N_{\text {leach_30 }}=I N_{\text {fert }} * D_{\text {fert }} \\
& S E_{\text {l30 }}=\left|N_{\text {leach_30 }}\right| * \sqrt{\left(S E_{\text {fert }} / I N_{\text {fert }}\right)^{2}+\left(S E_{d f} / D\right)^{2}} \\
& N_{\text {leach_365 }}=\sum_{i=1}^{m} N_{\text {leach_30i }}+I N_{\text {bkgd }} * D_{\text {bkgd }} \\
& S E_{\text {l365 }}=\sqrt{\sum_{i=1}^{m} S E_{130 i}^{2}+S E_{l b}^{2}} \\
& S E_{l b}=\left|I N_{\text {bkgd }} * D_{b k g d}\right| \\
& * \sqrt{\left(S E_{b k g d} / I N_{\text {bkgd }}\right)^{2}+\left(S E_{d b} / D_{b k g d}\right)^{2}}
\end{aligned}
$$

where $\quad \mathrm{IN}_{\text {fert }} \pm \mathrm{SE}_{\text {fert }} / \mathrm{D}_{\text {fert }} \pm \mathrm{SE}_{\mathrm{df}} \quad$ and $\mathrm{IN}_{\text {bkgd }} \pm \mathrm{SE}_{\mathrm{bkgd}} / \mathrm{D}_{\text {bkgd }} \pm \mathrm{SE}_{\mathrm{db}}$ represent the mean \pm SE of inorganic N (IN) concentrations/drainage in soil leaching solution following fertilization and at background levels, and $\mathrm{SE}_{\mathrm{lb}}$ represents the error (SE) of the total leaching IN in the months without fertilization in 2010; $\mathrm{m}$ represent the number of months with fertilization ( $m=4$ for Typical and Low Input, $m=1$ for Low Impact).

Residual $\mathrm{N}$ fluxes and potential changes in $\mathrm{N}$ stocks (soil and roots)

Residual $\mathrm{N}$ fluxes $\left(\mathrm{N}_{\mathrm{R}} \pm \mathrm{SE}_{\mathrm{r}}\right)$, or the difference between $\mathrm{N}$ outputs and inputs, were calculated for each lawn at both 30-day and annual scales as

$$
\begin{aligned}
& N_{R}=N_{\text {total }}-N_{\text {clip }}-N_{\mathrm{NH}_{3}}-N_{\mathrm{N}_{2}+\mathrm{N}_{2} \mathrm{O}}-N_{\text {leach }} \\
& S E_{R}=\sqrt{S E_{t}^{2}+S E_{p}^{2}+S E_{\mathrm{NH}_{3}}^{2}+S E_{\mathrm{N}_{2}+\mathrm{N}_{2} \mathrm{O}}^{2}+S E_{l}^{2}}
\end{aligned}
$$

where $\left(N_{\text {clip }} \pm \mathrm{SE}_{\mathrm{p}}\right)$ represents the $\mathrm{N}$ output in plant clippings calculated from Eqs. (4a)-(4c) $\left(N_{\mathrm{NH}_{3}} \pm \mathrm{SE}_{\mathrm{NH}_{3}}\right)$ and $\left(N_{\mathrm{N}_{2}+\mathrm{N}_{2} \mathrm{O}} \pm \mathrm{SE}_{\mathrm{N}_{2}+\mathrm{N}_{2} \mathrm{O}}\right)$ represent the fluxes of $\mathrm{NH}_{3}$ and $\mathrm{N}_{2}+\mathrm{N}_{2} \mathrm{O}$, calculated from Eqs. (5a)-(5d), and $\left(N_{\text {leach }} \pm \mathrm{SE}_{1}\right)$ represent $\mathrm{N}$ leaching losses, calculated from Eqs. (7a)-(7e). We did not include estimated NO fluxes in the residual 
calculation, as these were not directly measured; in addition, our estimates indicated that NO fluxes likely represent a very small portion of the $\mathrm{N}$ inputs.

Soil $\mathrm{N}$ immobilization/mineralization potentials $(0-10 \mathrm{~cm})$ at the 30 day scale $\left(\mathrm{N}_{\text {soil_30 }} \pm \mathrm{SE}\right)$ were estimated by 30 day lab incubation (Wang and Zhu 2012; Zhu and Carreiro 1999; Zhu and Wang 2011) of soil samples with $\left(\mathrm{N}_{\mathrm{FS}}\right)$ or without $\left(\mathrm{N}_{\mathrm{NFS}}\right) \mathrm{N}$ addition. Briefly, to determine the net $\mathrm{N}$ mineralization and net nitrification potentials of the lawn soils, a set of prefertilization soil cores were taken from the Typical and Low Input lawns in March 2010 and from the Low Impact lawn in March 2011 at five random locations each, 3 cores per location. The 3 cores from the same location were combined into one sample, sieved, and homogenized. Soil net N potentials were determined by incubating subsets ( $\sim 10$ g each, $n=5$ ) of sieved soils at room temperature and field moisture levels for 30 days. The incubated soils, as well as a subset of soils before incubation, were extracted with $1.5 \mathrm{M}$ $\mathrm{KCl}$ and measured for IN concentrations $\left(\mathrm{NH}_{4}{ }^{+}-\mathrm{N}\right.$ and $\left.\mathrm{NO}_{3}{ }^{-}-\mathrm{N}\right)$. The net potentials of soil $\mathrm{N}$ mineralization (or immobilization) and nitrification $\left(\mu \mathrm{g} \mathrm{N} \mathrm{g}^{-1}\right.$ dry soil day ${ }^{-1}$ ) were calculated as:

Net $\mathrm{N}$ mineralization (or immobilization)

$$
=\frac{\left(\mathrm{IN}_{\text {final }}-\mathrm{IN}_{\text {initial }}\right)}{\mathrm{T}_{\text {incu }}}
$$

Net nitritication $=\frac{\left(\mathrm{NO}_{3}^{-} \mathrm{N}_{\text {final }}-\mathrm{NO}_{3}^{-} \mathrm{N}_{\text {initial }}\right)}{\mathrm{T}_{\text {incu }}}$

where $\mathrm{IN}_{\text {initial }}$ and $\mathrm{IN}_{\text {final }}$ were the soil IN concentrations before and after incubation, $\mathrm{NO}_{3}{ }^{-} \mathrm{N}_{\text {initial }}$ and $\mathrm{NO}_{3}{ }^{-} \mathrm{N}_{\mathrm{f}-}$ inal were the $\mathrm{NO}_{3}{ }^{-} \mathrm{N}$ concentrations before and after incubation, and $\mathrm{T}_{\text {incu }}$ was the incubation time. Two sets of soils were incubated, one as "Control", and the other as "Plus-N", to which high-concentration ammonium chloride $\left(\mathrm{NH}_{4} \mathrm{Cl}\right)$ solution was added at a rate equivalent to the fertilization rates they receive in the field. The annual change in soil $\mathrm{N}$ stocks $\left(\mathrm{N}_{\text {soil_365 }} \pm \mathrm{SE}_{s}\right)$ due to soil $\mathrm{N}$ immobilization was estimated as

$N_{\text {soil__365 }}=m * N_{F S}+n * N_{N F S}$

$S E_{S 365}=\sqrt{m * S E_{F S}^{2}+n * S E_{N F S}^{2}}$

where $m$ and $n$ are the number of months with or without fertilizer application in $2010(m=4, n=8$ for Typical and Low Input, $m=1, n=11$ for Low Impact).
We also assessed soil $\mathrm{N}$ retention with other methods for comparison. We made direct measurements of soil N\% and root biomass $\mathrm{N}$ in 2010 and 2011: five soil cores each were collected from each lawn before fertilization in March, 2010 and 2011 to assess the annual differences. Soils were sieved to $2 \mathrm{~mm}$, homogenized, oven dried for $48 \mathrm{~h}$ at $110{ }^{\circ} \mathrm{C}$, weighed, ground to fine powder, and analyzed for total $\mathrm{C} \%$ and $\mathrm{N} \%$ on the elemental analyzer. We assumed no significant variation in soil bulk density during our study period, and averaged the bulk density of soil cores in each lawn, which were $1.2 \pm 0.03$, $0.81 \pm 0.04$, and $1.2 \pm 0.1 \mathrm{Mg} \mathrm{m}^{-1}$ for Typical, Low Input, and Low Impact, respectively. In order to assess the variation in root $\mathrm{N}$ content between 2010 and 2011, roots $(\geq 2 \mathrm{~mm}$ ) were separated from the soil cores described above, oven dried for $48 \mathrm{~h}$ at $70{ }^{\circ} \mathrm{C}$, weighed, ground to fine powder, and analyzed for total $\mathrm{C} \%$ and $\mathrm{N} \%$. The total $\mathrm{N}$ mass in soil or roots was calculated as the product of density and N\%. To account for possible variation in root $\mathrm{N}$ at the 30 day scale, another 5 soil cores were sampled from each lawn 30 days after fertilization in March 2011 and the roots were separated and analyzed for total $\mathrm{C} \%$ and $\mathrm{N} \%$.

Data analysis and residual calculation

$\mathrm{N}$ budgets were constructed for Typical and Low Input at a 30-day scale following each of the 6 fertilization events from January 2010 to June 2011 and for all lawns at an annual scale for 2010. Repeated measures ANOVA was used to test the effects of lawn type, time (day), and their interactions (lawn type*day) on the daily averages of soil volumetric water content, while an $F$ test was used to compare the variances of the daily averages. Nested Analysis of Variance (ANOVA) was used to compare IN concentrations of lysimeter samples below the rooting zones $(40 \mathrm{~cm})$ and denitrification rates, with time (day) as the nominal factor nested in lawn types. Multivariate regression analyses were used to evaluate the relationship between denitrification rates and potential driving variables (soil water content and $\mathrm{NO}_{3}{ }^{-}-\mathrm{N}$ concentrations), and the relationship between plant productivity and environmental factors (air temperature, soil water content, and plant $\mathrm{N} \%$, as an indicator of $\mathrm{N}$ availability). We used ANOVA tests to compare the soil total $\mathrm{C} \%, \mathrm{~N} \%$, and net $\mathrm{N}$ potentials among the three lawns, and Student's $t$ tests $(\alpha=0.05)$ to compare these variables in 2010 and 2011, as well 
as root densities and root N\% of roots at the 30-day and annual scales. All analyses were performed with SAS software v9.1.3 (SAS, Cary, NC, USA).

\section{Results}

Climatic data

During our study period, air and soil temperatures ranged from 6.2 to $28.9{ }^{\circ} \mathrm{C}$ and 8.3 to $25.3{ }^{\circ} \mathrm{C}$, respectively. The total annual rainfall at our study site in 2010 was $995.2 \mathrm{~mm}$, with monthly rainfall highest in December (269.5 mm) and almost none from June to September. Irrigation rates varied greatly among the three lawns as well as among seasons (Fig. 1). During summer 2010, the irrigation rates were as high as 350-400 mm month ${ }^{-1}$ for Typical and 100-150 $\mathrm{mm} \mathrm{month}{ }^{-1}$ for the other two lawns, while in winter

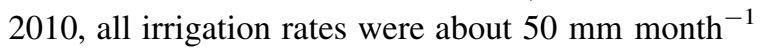
or lower. Daily average soil volumetric water content ranged from $13.4 \pm 0.5$ to $19.3 \pm 0.7 \%$ in Typical, from $11.6 \pm 0.9$ to $19.6 \pm 0.4 \%$ in Low Input, and from $18.45 \pm 2.48$ to $22.92 \pm 4.79$ in Low Impact. Over the entire study period, the Low Impact site had the highest daily average soil moisture $(20.2 \%$ $\pm 0.04)$ followed by the Typical $(16.8 \% \pm 0.03)$ and the Low Input $(15.5 \% \pm 0.03, P<0.0001$, repeated measures ANOVA).

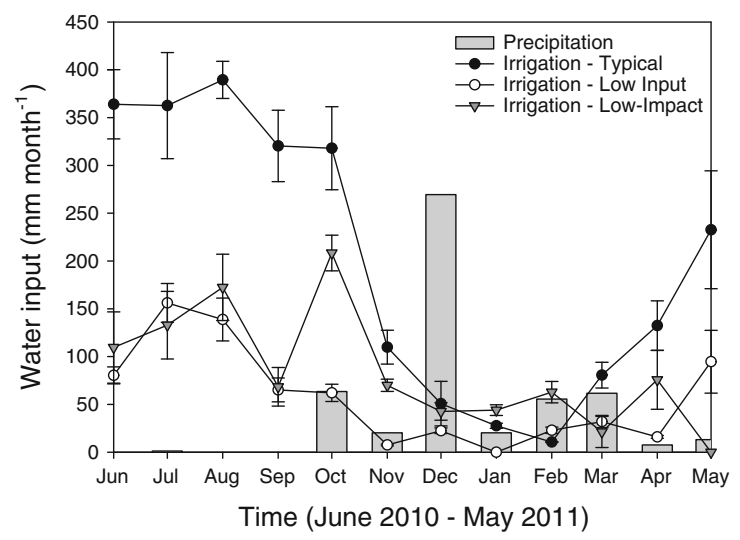

Fig. 1 Monthly precipitation (gray bars) and irrigation in Typical (filled circles), Low Input (blank circles) and Low Impact (gray triangles) from June 2010 to May 2011. Data are shown as mean $\pm \mathrm{SE}$
$\mathrm{N}$ inputs from fertilization, atmospheric deposition and irrigation water

Fertilization, atmospheric deposition, and irrigation water contributed 76-90,7-23, and $1 \%$, respectively, of the total $\mathrm{N}$ inputs to the lawns (Table 1a). The bulk atmospheric $\mathrm{N}$ deposition during the collection period was $0.69 \mathrm{~kg} \mathrm{~N} \mathrm{ha}^{-1}$ (or $1.1 \mathrm{~kg} \mathrm{ha}^{-1} \mathrm{year}^{-1}$ ) for $\mathrm{NH}_{4}{ }^{+}-\mathrm{N} \quad(n=1)$ and $0.68 \pm 0.08 \mathrm{~kg} \mathrm{~N}^{-1}$ (or $1.1 \pm 0.1 \mathrm{~kg} \mathrm{~N}^{-1}$ year $\left.^{-1}\right)$ for $\mathrm{NO}_{3}{ }^{-}-\mathrm{N} \quad(n=5)$. The total irrigation volumes from June 2010 to May 2011 were $2,399 \pm 298 \mathrm{~mm}$ for Typical, $698 \pm 112 \mathrm{~mm}$ for Low Input, and 1,008 $\pm 226 \mathrm{~mm}$ for Low Impact. The average $\mathrm{NH}_{4}{ }^{+}-\mathrm{N}$ and $\mathrm{NO}_{3}{ }^{-}-\mathrm{N}$ concentrations in irrigation water in 2010 were $0.07 \pm 0.01$ and $0.02 \pm 0.01 \mathrm{ppm}(n=5)$.

$\mathrm{N}$ outputs in plant clippings

The overall clipping biomass removed from the Typical, Low Input, and Low Impact lawns in 2010 was 2,674, 3,866, and $772 \mathrm{~kg} \mathrm{ha}^{-1}$ year $^{-1}$ (Fig. 2a), while the mean $\mathrm{N} \%$ in plant clippings was $2.6 \pm 0.1,2.1 \pm 0.1$, and $1.0 \pm 0.1 \%$, respectively (Fig. 2b); the clipping biomass $\mathrm{N}$ was $69.2 \pm 0.5,74.1 \pm 0.5$, and $7.7 \pm$ $0.4 \mathrm{~kg} \mathrm{~N} \mathrm{ha}^{-1}$ year $^{-1}$ (Fig. 2c), which accounted for about 33,54 , and $12 \%$ of the total annual $\mathrm{N}$ inputs in 2010 (Table 1b). In the 30-day periods after fertilization, the average growth rates of the Typical and Low Input lawns were $1.2 \pm 0.2$ and $1.7 \pm 0.7 \mathrm{~g}$ biomass $\mathrm{m}^{-2}$ day $^{-1}$, compared to their annual growth rates of 0.73 and $1.1 \mathrm{~g}$ biomass $\mathrm{m}^{-2}$ day $^{-1}$; the average 30-day clipping biomass and biomass $\mathrm{N}$ were $351 \pm$ $36 \mathrm{~kg} \mathrm{ha}^{-1}$ and $9.3 \pm 0.01 \mathrm{~kg} \mathrm{~N}^{-1}$ for Typical and $507 \pm 116 \mathrm{~kg} \mathrm{ha}^{-1}$ and $12.1 \pm 0.1 \mathrm{~kg} \mathrm{~N} \mathrm{ha}^{-1}$ for Low Input, while the individual 30-day clipping biomass $\mathrm{N}$ of six fertilization periods accounted for 12-33 and 9-87\% of their respective fertilization rates (Table 1b; Fig. 3).

Interestingly, multivariate regression analysis showed that the aboveground productivity of seashore paspalum in Low Input was positively affected by both plant $\mathrm{N} \%\left(P=0.0146\right.$, partial $\left.\mathrm{R}^{2}=0.2930\right)$, an indicator of available $\mathrm{N}$ for plant uptake, and average air temperature $\left(P=0.0012\right.$, partial $\left.\mathrm{R}^{2}=0.4714\right)$, while that of tall fescue in Typical only increased with plant N\% $\left(P=0.0316\right.$, adj. $\left.\mathrm{R}^{2}=0.2553\right)$. At half the fertilization rate as tall fescue, seashore paspalum had higher clipping biomass $\mathrm{N}$ in the 30 -day periods after fertilization than tall fescue in May, while the opposite 


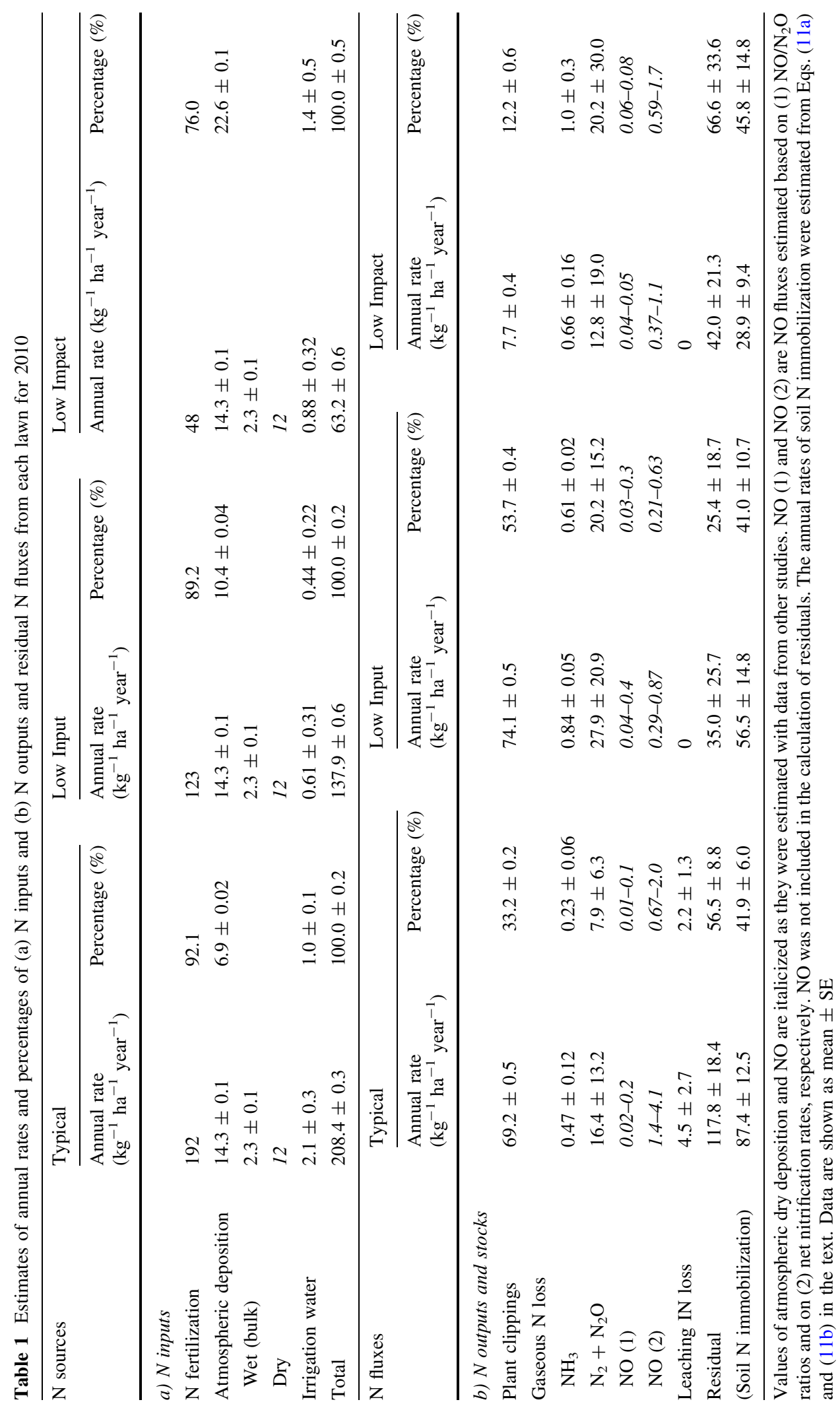


Fig. 2 Time series of a aboveground productivity (top panel), b clipping N\% (middle panel), and c clipping biomass $\mathrm{N}$ (bottom panel) of tall fescue (Schedonorus phoenix) in Typical (filled triangles) and seashore paspalum (Paspalum vaginatum) in Low Input (open triangles) from Jan 2010 to June 2011. The vertical lines show the fertilization dates (March 29, May 24, August 16, and September 21, 2010; March 08/Mar 29 for Typical/Low Input, May 16, 2011). Data are shown as mean $\pm \mathrm{SE}$

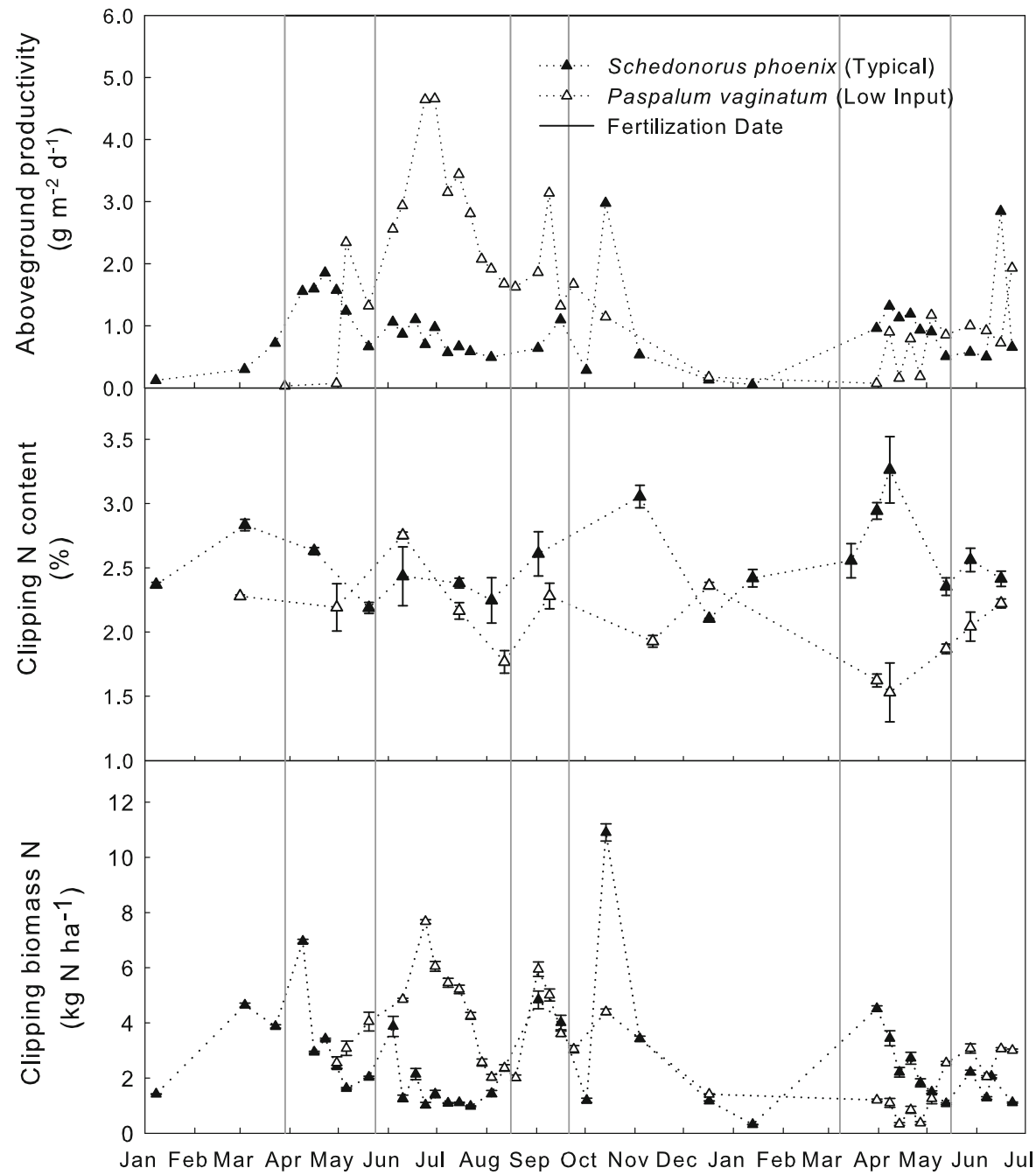

was true in September and March (all $P<0.0001$ ). In August 2010, the only period when the two lawns were fertilized at the same rate, seashore paspalum obtained twice as much biomass $\mathrm{N}$ as tall fescue.

Soil net $\mathrm{N}$ potentials and leaching $\mathrm{N}$ losses

In the 30-day lab incubation, soils from Typical and Low Input lawns showed net $\mathrm{N}$ mineralization in the Control treatment of $1.6 \pm 0.7$ and $1.2 \pm 1.1$ $\mathrm{kg} \mathrm{N}^{-1}$ month $^{-1}$ and net $\mathrm{N}$ immobilization in the Plus- $\mathrm{N}$ treatment as equivalent to $25.2 \pm 2.7$ and $16.4 \pm 3.4 \mathrm{~kg} \mathrm{~N} \mathrm{ha}^{-1}$ month $^{-1}$. Soils from Low Impact showed net $\mathrm{N}$ immobilization in both Control and Plus $\mathrm{N}$ treatments, as $1.2 \pm 0.4$ and $16.3 \pm 5.2 \mathrm{~kg} \mathrm{~N} \mathrm{ha}^{-1}$ month $^{-1}$. Soil net nitrification potentials significantly increased with $\mathrm{N}$ addition in all three types of soils $(P<0.05)$, from $0.54 \pm 0.25$ to $32.2 \pm 2.5$, from undetectable to $6.7 \pm 3.4$, and from $0.6 \pm 0.6$ to $37.2 \pm 9.2 \mathrm{~kg} \mathrm{~N} \mathrm{ha}^{-1}$ month $^{-1}$ in Typical, Low Input, and Low Impact, respectively. In the Plus-N treatment, Typical and Low Impact had significantly higher net nitrification rates than Low Input $(P<0.0001)$, while the soil net $\mathrm{N}$ immobilization potentials were not significantly different among the three lawns.

The pre-fertilization IN concentrations in the soil solutions at $40 \mathrm{~cm}$ were generally low or undetectable. $\mathrm{NH}_{4}{ }^{+}-\mathrm{N}$ concentrations peaked sharply in 1-3 days following fertilization; such post-fertilization $\mathrm{NH}_{4}{ }^{+}-\mathrm{N}$ peaks varied among seasons in both Typical $(P=0.0011)$ and Low Input $(P=0.0095)$, with both 


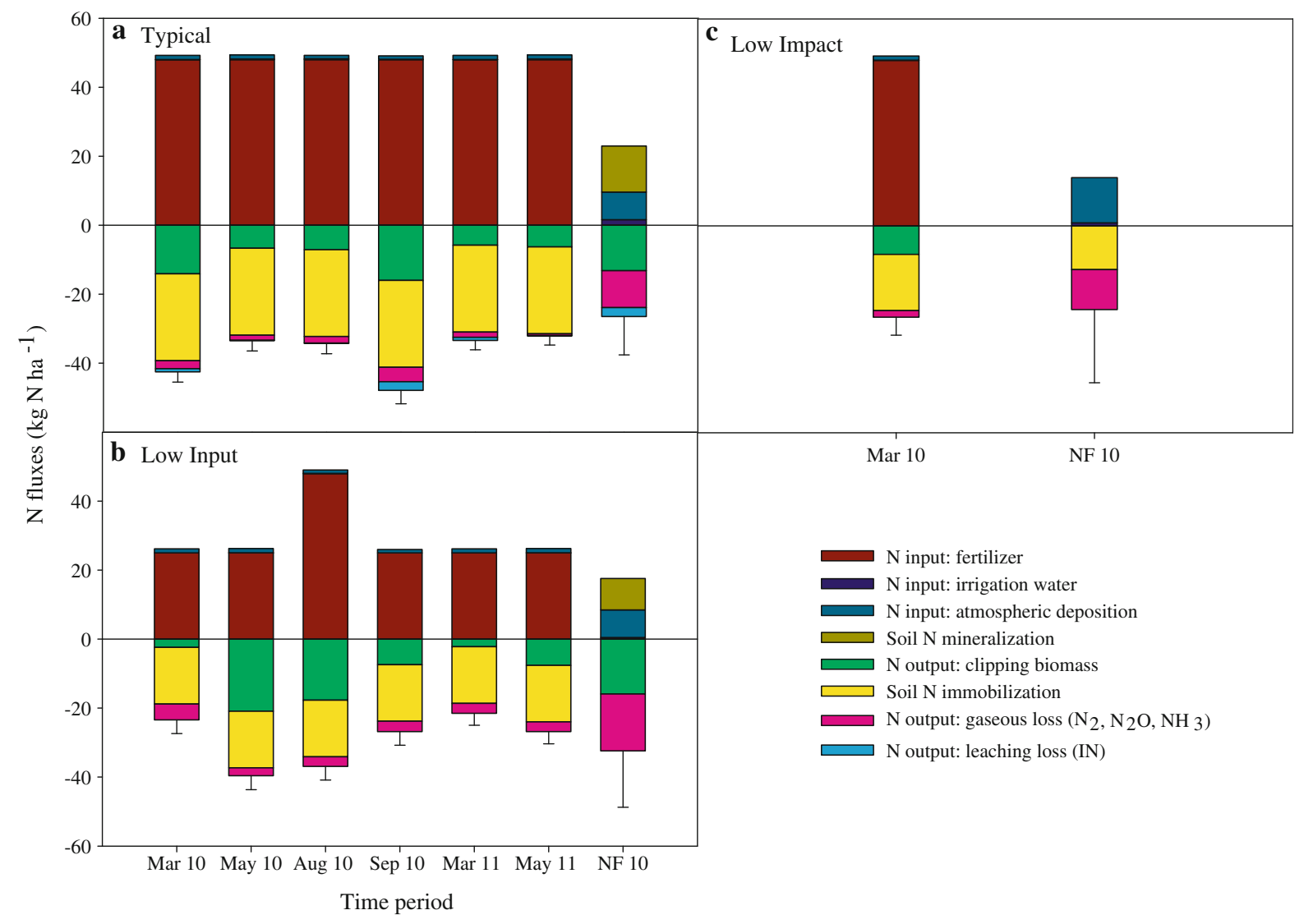

Fig. 3 Inputs and outputs of reactive $\mathrm{N}$ to soil in the a Typical, b Low Input, and c Low Impact lawns during the 30-day periods following fertilization events in 2010 and 2011 (Mar 10, May 10, Aug 10, Sep 10, Mar 11, and May 11) and the non-fertilized

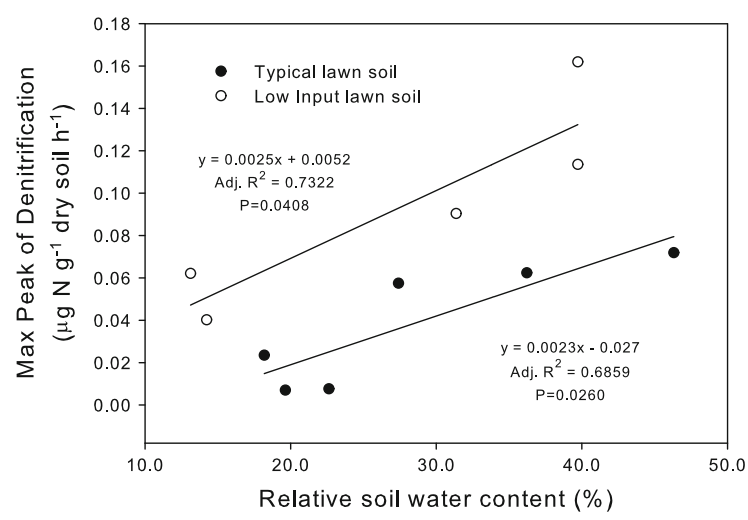

Fig. $4 \mathrm{NH}_{3}$ volatilization in Typical (filled squares), Low Input (gray squares), and Low Impact (dark gray squares) following fertilization. In March 2011, Typical and Low Impact were fertilized on the 8th while Low Input was fertilized on the 29th. Data are shown as mean \pm SE. The fertilization dates (Day 1) are shown in each panel period in 2010 (NF 10, 245 days). The error bars show propagated uncertainties (SE) of all inputs or outputs. (Color figure online)

maximums seen in March 2011. $\mathrm{NO}_{3}{ }^{-} \mathrm{N}$ concentrations were generally low to undetectable with no apparent seasonal variations. The precipitation/ET $\mathrm{ET}_{0}$ rates from the CIMIS network were 0/149, 53/83, $63 / 99,9 / 129 \mathrm{~mm}$ in 30 days following the last 4 fertilization events and $397 / 542 \mathrm{~mm}$ for the rest of year (245 days). The corresponding drainage volumes were $181,288,88,113$, and $1278 \mathrm{~mm}$ for Typical but zero for the other two lawns. Therefore, the leaching IN was about $2 \%$ of the annual $\mathrm{N}$ inputs to Typical and none in the other two lawns (Table 1b).

Gaseous and leaching $\mathrm{N}$ losses

$\mathrm{NH}_{3}$ fluxes peaked and declined quickly following fertilization (Fig. 4). The average $\mathrm{NH}_{3}$ volatilization in 30 days was $0.06 \pm 0.01$ and $0.13 \pm 0.02 \mathrm{~kg} \mathrm{~N} \mathrm{ha}^{-1}$ 
month $^{-1}$ from Typical and Low Input following the 6 fertilization events, and $0.35 \pm 0.02 \mathrm{~kg} \mathrm{~N} \mathrm{ha}^{-1}$ month $^{-1}$ for Low Impact following the fertilization on March 8, 2011. The background $\mathrm{NH}_{3}$ fluxes were similar in the three lawns, about $0.001 \pm 0.001 \mathrm{~kg} \mathrm{~N} \mathrm{ha}^{-1}$ day $^{-1}$. The annual $\mathrm{NH}_{3}$ loss in 2010 was no more than $1 \%$ of $\mathrm{N}$ inputs from each lawn (Table $1 \mathrm{~b}$ ).

The total denitrification potentials were $10-100$ times higher than $\mathrm{NH}_{3}$ volatilization at both time scales. The denitrification rates in 30 days following fertilization were $1.3 \pm 0.2, \quad 4.0 \pm 0.3$, and $1.5 \pm 0.3$ $\mathrm{kg} \mathrm{N}^{-1}$ month $^{-1}$ in Typical, Low Input (both $n=6$ ), and Low Impact ( $n=1$, Fig. 5). The background denitrification rates were $0.04 \pm 0.04$, $0.07 \pm 0.09, \quad$ and $0.03 \pm 0.06 \mathrm{~kg} \mathrm{~N} \mathrm{ha}^{-1}$ day $^{-1}$, respectively. Denitrification accounted for up to $3.5 \pm 2.9,17.5 \pm 8.4$, and $3.1 \pm 1.3 \%$ of $\mathrm{N}$ inputs from a single application of the lawns, and $7.9 \pm 6.3$, $20.2 \pm 15.2$, and $20.2 \pm 30.0 \%$ of their annual $\mathrm{N}$

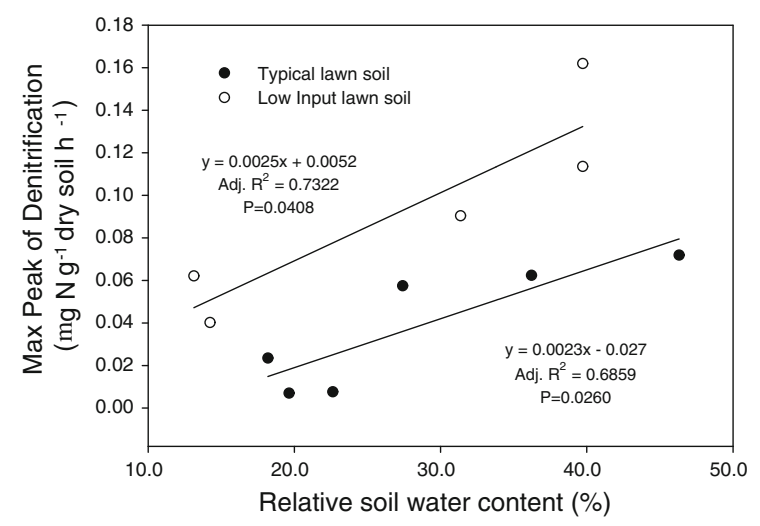

Fig. 6 Relationship between the maximum denitrification rate following each fertilization event and the relative soil water content in Typical and Low Input

inputs. Although Low Input received only half the fertilization rate as Typical, it showed significantly higher soil denitrification potentials following 4 out of 6

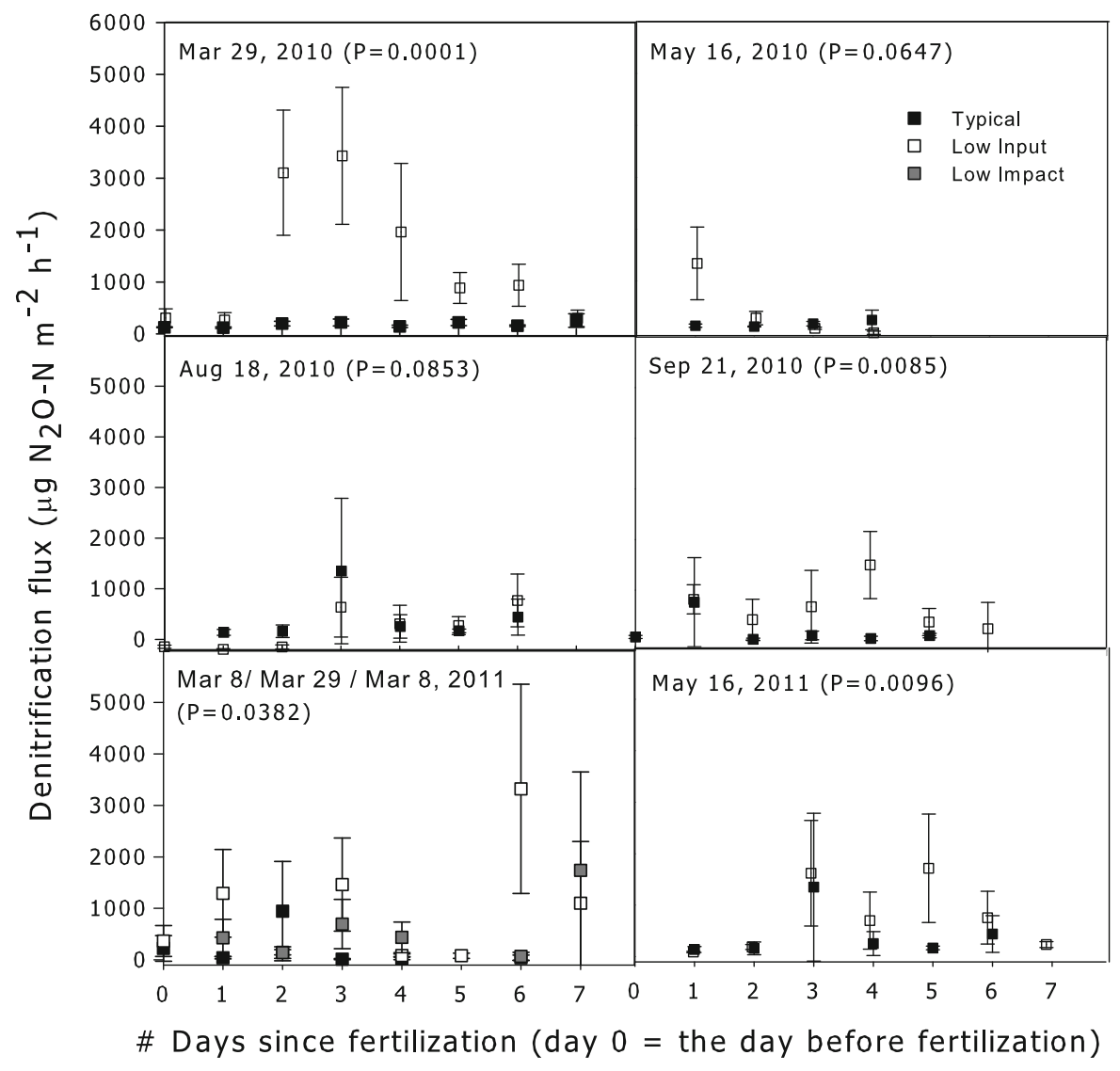

Fig. 5 Denitrification fluxes in Typical (filled squares), Low Input (empty squares), and Low Impact (gray squares) following each of the 6 fertilization events in 2010 and 2011.
$\mathrm{P}$ values are from an ANOVA with time (day) as the nominal factor nested in lawn types. Error bars represent the standard error. The fertilization dates (Day 1) were given in each panel 
fertilization events $(P<0.05)$. There was no significant relationship between denitrification and soil $\mathrm{NO}_{3}{ }^{-}-\mathrm{N}$ or soil relative water content. However, the maximum peak of denitrification during each fertilization period was correlated with soil relative water content (Fig. 6).

$\mathrm{N}_{2} \mathrm{O}$ fluxes after fertilization were relatively low or even undetectable in many cases. Peak $\mathrm{N}_{2} \mathrm{O}$ fluxes ranged from $3.4 \pm 3.4$ to $19.5 \pm 11.3 \mu \mathrm{g} \mathrm{N} \mathrm{m}^{-2} \mathrm{~h}^{-1}$ for Typical and from $9.1 \pm 5.9$ to $54.6 \pm$ $10.4 \mu \mathrm{g} \mathrm{N} \mathrm{m}^{-2} \mathrm{~h}^{-1}$ for Low Input. There was a single peak of $1.99 \pm 1.99 \mu \mathrm{g} \mathrm{N} \mathrm{m}^{-2} \mathrm{~h}^{-1}$ in Low Impact following fertilization on March 8, 2011, but no detectable $\mathrm{N}_{2} \mathrm{O}$ flux otherwise. NO emissions estimated based on $\mathrm{N}_{2} \mathrm{O}$ fluxes were lower than $0.1 \%$ of the annual $\mathrm{N}$ inputs, while values estimated based on net nitrification rates accounted for less than $2 \%$.

\section{Residual $\mathrm{N}$ fluxes and change in soil $\mathrm{N}$ stocks}

The residual $\mathrm{N}$ fluxes ranged from $28.9 \pm 2.9$ to $42.6 \pm 0.2$ and from $3.1 \pm 2.2$ to $21.1 \pm 0.8$ $\mathrm{kg} \mathrm{N} \mathrm{ha}^{-1}$ month $^{-1}$ in the Typical and Low Input lawns in the 30 days following fertilization. The annual residual $\mathrm{N}$ fluxes were $117.8 \pm 18.4,35.0 \pm 25.7$, and $42.0 \pm 21.3 \mathrm{~kg} \mathrm{~N}^{-1}$ year $^{-1}$ in Typical, Low Input, and Low Impact (Table 1b). Soil net $\mathrm{N}$ immobilization accounted for $52.5 \pm 5.2,68.3 \pm 14.2$, and $33.9 \pm 10.8 \%$ of $\mathrm{N}$ inputs from a single fertilization to these lawns on average, and about $41.9 \pm 6.0$, $41.0 \pm 10.7$, and $45.8 \pm 14.8 \%$ annually (Table $1 \mathrm{~b}$ ). However, we were unable to detect any significant 30-day or annual variation in root density (live and dead), root $\mathrm{N} \%$, root $\mathrm{N}$ mass, or annual variation of soil $\mathrm{N} \%$ in any lawn. The total $\mathrm{C} \%$ of $0-10 \mathrm{~cm}$ soil was $2.3 \pm 0.6,5.8 \pm 1.2$, and $1.78 \pm 0.4 \%$ for Typical, Low Input, and Low Impact ( $n=6$ each), while the corresponding total $\mathrm{N} \%$ was $0.15 \pm 0.04,0.38 \pm 0.08$, and $0.10 \pm 0.03 \%$. The average $\mathrm{C}: \mathrm{N}$ ratios were $14.4 \pm 0.6,15.6 \pm 0.2$, and $17.7 \pm 0.5$, respectively. The soil $\mathrm{C} \%$ and $\mathrm{N} \%$ were highest in Low Input and lowest in Low Impact $(P<0.0001)$, while the $\mathrm{C}: \mathrm{N}$ ratios were highest in Low Impact and lowest in Typical $(P<0.0001)$.

\section{Discussion}

In this study, clipping biomass and mineral soil were primary $\mathrm{N}$ sinks at both 30 -day and annual scales
(Fig. 3). At half the fertilization rates as Typical, the seashore paspalum clippings from Low Input accounted for an average of $33 \%$ of $\mathrm{N}$ inputs in 30 days and $54 \%$ at the annual scale, compared to 19 and $33 \%$ in tall fescue of Typical and $12 \%$ (annual) in the Carex of Low Impact. However, Low Input also had higher post-fertilization denitrification rates most of the time. Due to relatively low IN concentrations in leaching solution, the leaching IN loss was low (2\%) from Typical and estimated as zero (undetectable) in Low Input and Low Impact. The gaseous $\mathrm{N}$ losses were of similar magnitudes in all three lawns, dominated by denitrification. However, due to relatively large uncertainties, denitrification rates have a large possible range (Table 1b).

$\mathrm{N}$ output in plant clippings

The 30-day clipping biomass $\mathrm{N}$ after fertilization of tall fescue and seashore paspalum was $19.4 \pm 3.8$ and $30.4 \pm 11.1 \%$ of $\mathrm{N}$ input from single application, compared to the annual $\mathrm{N}$ output in clipping biomass of 33 and $54 \%$ of the annual $\mathrm{N}$ input. Therefore, in our study where clippings were removed from the lawns, clipping biomass represented an important $\mathrm{N}$ output in the short term as well as the long term (Fig. 3; Table 1b). While many studies similarly found plant biomass and mineral soils as the primary $\mathrm{N}$ sinks in lawns, their magnitudes varied over time and differed depending on whether grass clippings were removed or returned to lawns. Engelsjord et al. (2004) showed that when all clippings in experimental turf plots were regularly collected, ${ }^{15} \mathrm{~N}$-labeled fertilizer $\mathrm{N}$ accumulated in clipping biomass over a year (from about $21-25$ to $40-46 \%$ ), while ${ }^{15} \mathrm{~N}$ recovery in $0-40 \mathrm{~cm}$ soil gradually decreased (from about 20-27 to 9-14\%). However, when clippings were left in place, labeled fertilizer $\mathrm{N}$ retained in mineral soil increased over time and became the dominant long-term pool (from 20 to $33 \%$ ), while plant biomass only dominated the short-term recovery of ${ }^{15} \mathrm{~N}$ label but not the long term (from 30 to less than $10 \%$, Raciti et al. 2008). Frank et al. (2006) also reported high retention of ${ }^{15} \mathrm{~N}$-labeled fertilizer $\mathrm{N}$ in soil (43-67 \%) and much smaller ${ }^{15} \mathrm{~N}$ in clipping biomass $(7-9.7 \%)$ in 2 years' time. We did not measure the thatch $\mathrm{N}$ in our studies because there was no visible thatch layer or verdure left after mowing at our sites, such that this was likely 
a very small portion of the annual $\mathrm{N}$ output, if any (Engelsjord et al. 2004; Frank et al. 2006).

Even at half the rate of fertilization as tall fescue and about one-third of the irrigation, seashore paspalum had a higher annual growth rate than tall fescue (1.06 vs. $0.73 \mathrm{~g}$ biomass $\mathrm{m}^{-2} \mathrm{day}^{-1}$ ) in 2010 and a similar annual $\mathrm{N}$ output in turf clippings $(74.1 \pm 0.5$ vs. $69.2 \pm 0.5 \mathrm{~kg}^{-1} \mathrm{ha}^{-1}$ year $^{-1}$ ) at a lower mean plant N\% (Table 1b). Considering their fertilization rates, seashore paspalum was nearly twice as efficient in plant $\mathrm{N}$ uptake (54\% of annual $\mathrm{N}$ inputs) as the tall fescue in Typical (33 \%). The Carex in Low Impact required the lowest $\mathrm{N}$ fertilization rates of all, but also had the lowest $\mathrm{N}$ uptake efficiency, only $12 \%$ of the annual $\mathrm{N}$ inputs. In addition, the $\mathrm{ET}_{0}$-based irrigation system did not result in a lower water input than the soil moisture-based system $(1,008 \pm 226$ vs. $698 \pm 112 \mathrm{~mm})$, though both were lower than the Typical lawn $(2,399 \pm 298 \mathrm{~mm})$. Denitrification rates and $\mathrm{N}_{2} \mathrm{O}$ fluxes were still high in Low Input compared to Typical, while inorganic $\mathrm{N}$ concentrations in leaching solutions were not significantly different from Typical, suggesting that the fertilization rates might still have been greater than plant requirements and could be further reduced.

$\mathrm{C}_{4}$ species are known for their high efficiency in water and $\mathrm{N}$ usage and consequentially high productivity at lower plant $\mathrm{N} \%$ than $\mathrm{C}_{3}$ species, especially under warm temperatures (Long 1999). Throughout the study period, the growth rate of seashore paspalum was positively affected by both air temperature and plant $\mathrm{N} \%$ (as an indicator of $\mathrm{N}$ availability), while that of tall fescue was only affected by plant N\%. Biomass $\mathrm{N}$ in tall fescue clippings peaked in cool seasons while biomass $\mathrm{N}$ of seashore paspalum peaked in warmer seasons (Fig. 2c); the former was higher than the latter in March 2010, September 2010, and March 2011, while the opposite was true for May 2010 and August 2010. Wherley et al. (2009) also reported a similar seasonal pattern associated with temperature in a $\mathrm{C}_{4}$ turf species (bermudagrass), which assimilated as much as $49 \%$ of ${ }^{15} \mathrm{~N}$-labeled fertilizer $\mathrm{N}$ in 16 days in August, about $25 \%$ in May and October, but none in January. High productivity of seashore paspalum might have promoted accumulation of organic $\mathrm{C}$ in the soil of Low Input, and in turn, $\mathrm{N}$ immobilization and retention in soil. Low Input was higher than Typical in soil C\% $(5.8 \pm 1.2$ vs. $2.3 \pm 0.6 \%)$ and $\mathrm{N} \% \quad(0.38 \pm 0.08$ vs. $0.15 \pm 0.04 \%)$. Under simulated $\mathrm{N}$ fertilization, soil net immobilization rates in both lawns were similar $(0.94 \pm 0.11$ vs. $0.71 \pm 0.12 \mu \mathrm{g} \mathrm{N} \mathrm{g}^{-1}$ dry soil day ${ }^{-1}$ ), despite the lower fertilization rate in Low Input. We were not able to directly compare the soil $\mathrm{C}$ and $\mathrm{N}$ accumulation rates in the two lawns due to the lack of soil data at lawn establishment. Since plant clippings were removed after mowing, the accumulation of $\mathrm{C}$ and $\mathrm{N}$ largely depended on belowground productivity, which we did not measure directly, but was likely related to aboveground productivity.

$\mathrm{N}$ losses through gaseous and aqueous forms

Denitrification dominated gaseous $\mathrm{N}$ losses and was of similarly high magnitudes and temporal patterns in all three lawns, despite the differences in the fertilization and irrigation regimes. The daily average denitrification fluxes were higher in Low Input than Typical following 4 out of 6 fertilization events, which might be explained by the higher soil $\mathrm{C} \%$ and $\mathrm{N} \%$ in Low Input that could promote higher denitrification. However, there was a high degree of spatial variability in these fluxes and consequentially large uncertainties of $\mathrm{N}$ losses through this pathway. At the annual scale, gaseous $\mathrm{N}$ losses through denitrification were $16.4 \pm 13.2,27.9 \pm 20.9$, and $12.8 \pm 19.0 \mathrm{~kg}^{-1} \mathrm{ha}^{-1}$ year $^{-1}$ for Typical, Low Input, and Low Impact, compared to the mean denitrification rates of $13 \mathrm{~kg}^{-1} \mathrm{ha}^{-1}$ year ${ }^{-1}$ for fertilized agricultural soils estimated by Barton et al. (1999) and $14 \pm 3.6 \mathrm{~kg}^{-1} \mathrm{ha}^{-1}$ year $^{-1}$ for fertilized suburban lawns (Raciti et al. 2011b). Denitrification accounted for $7.9 \pm 6.3, \quad 20.2 \pm 15.2$, and $20.2 \pm 30.4 \%$ of total annual $\mathrm{N}$ inputs in Typical, Low Input, and Low Impact. With relatively large uncertainties due to spatial variation, the estimated fluxes at the annual scale might have a large possible range, from 0 to $50 \%$, of total $\mathrm{N}$ inputs (Table $1 \mathrm{~b}$ ). Relatively large gaseous $\mathrm{N}$ losses through denitrification are expected if $\mathrm{N}$ fertilization rates exceed plant needs (Barton et al. 1999; Raciti et al. 2011b), while long-term fertilization could substantially increase the denitrification potential of soil (Drury et al. 1997; Horgan et al. 2002b; Šimek et al. 2000). Although denitrification may help reduce $\mathrm{NO}_{3}{ }^{-}-\mathrm{N}$ leaching from fertilized lawns by converting $\mathrm{NO}_{3}{ }^{-}-\mathrm{N}$ to $\mathrm{N}_{2}$, high denitrification rates may also increase soil emissions of $\mathrm{NO}$, an air pollutant, and $\mathrm{N}_{2} \mathrm{O}$, a greenhouse gas. 
Increased soil moisture may positively affect soil net nitrification in semi-arid ecosystems (Wang and Pataki 2012) as well as soil denitrification due to anaerobic conditions (Davidson 1991), increasing the potential for gaseous $\mathrm{N}$ losses through nitrification and denitrification. We did not find a significant relationship between denitrification and soil $\mathrm{NO}_{3}{ }^{-}-\mathrm{N}$ or soil relative water content in this study; however, there was a positive correlation between the maximum peak of denitrification during each fertilization period and the corresponding relative soil water content (Fig. 6). Denitrification is usually concentrated in "hot spots" and "hot moments" due to the high spatial and temporal heterogeneities of its required conditions: organic $\mathrm{C}, \mathrm{NO}_{3}{ }^{-}-\mathrm{N}$, and anaerobic environments (Groffman et al. 2009a). Therefore, the maximum peak of denitrification in each sampling period might represent the "hot spots" of most concentrated substrates and preferable conditions combined. In other words, anaerobic conditions caused by high relative soil water content became a dominant factor affecting denitrification only in the presence of sufficient substrates. We may have underestimated or overestimated the field denitrification rates because of limited sample size and because soil moisture (field moisture) and temperature were kept constant within each set of the acetylene-blocking incubation soils. The acetylene-blocking method might also lead to underestimation of base denitrification, as $10 \%$ acetylene gas in the incubation jar could inhibit nitrification, reducing $\mathrm{NO}_{3}{ }^{-}-\mathrm{N}$ for denitrification process.

$\mathrm{N}_{2} \mathrm{O}$ emissions from all three lawns were mostly low or undetectable following fertilization. Peak fluxes from Typical $\left(3.4 \pm 3.4\right.$ to $\left.19.5 \pm 11.3 \mu \mathrm{g} \mathrm{N} \mathrm{m}^{-2} \mathrm{~h}^{-1}\right)$ were similar in magnitude to the natural desert sites measured by Hall et al. (2008), while peak fluxes from Low Input were 2-threefold higher $(9.1 \pm 5.9$ to $54.6 \pm 10.4 \mu \mathrm{g} \mathrm{N} \mathrm{m}^{-2} \mathrm{~h}^{-1}$ ) and closer to those reported by Hall et al. (2008) from urban lawns in Arizona (18 to $80 \mu \mathrm{g} \mathrm{N} \mathrm{m}^{-2} \mathrm{~h}^{-1}$ ). Usually, $\mathrm{N}_{2} \mathrm{O}$ emissions are much higher in fertilized urban soils than in natural ecosystems (Hall et al. 2008; Kaye et al. 2004); however, fertilization rates and $\mathrm{N}_{2} \mathrm{O}$ fluxes are not always correlated (Jungkunst et al. 2006; Townsend-Small et al. 2011). We did not directly measure NO fluxes from nitrification, but our estimated ranges of $\mathrm{NO}$ emissions based on either $\mathrm{NO} / \mathrm{N}_{2} \mathrm{O}$ ratios $(<0.1 \%)$ or net nitrification rates $(<2 \%)$ suggest that this is not a large possible pathway of $\mathrm{N}$ loss. The difference between the two estimates comes from a combination of low $\mathrm{N}_{2} \mathrm{O}$ emissions from actual measurements and relatively high nitrification potentials measured in lab incubations. Given that the nitrification potentials from lab incubations could differ from actual field nitrification because of the variation of temperature and moisture as well as differences in leaching conditions, the estimates based on lab nitrification potentials might deviate more from the actual NO emissions. Consequently, direct measurements of NO fluxes would be useful to verify this conclusion. $\mathrm{NH}_{3}$ losses through fertilizer volatilization were also minimal compared to denitrification as the values were less than $1 \%$ in our study (Table 1b) in all three lawns, probably because slow-release coated-urea was used. $\mathrm{NH}_{3}$ volatilization of urea-based fertilizer varies greatly among studies with fertilizer types and rates, but coated urea tends to have significantly lower volatilization rates than uncoated urea. Torello et al. (1983) reported $\mathrm{NH}_{3}$ volatilization of $0.2-10.3 \%$ of applied urea- $\mathrm{N}$ in various forms (prilled urea, coated urea, or dissolved urea, at $49-293 \mathrm{~kg} \mathrm{~N} \mathrm{ha}^{-1}$ ) to Kentucky bluegrass. Vaio et al. (2007) reported 12-46\% volatilization of urea- $\mathrm{N}$ (urea polymer, urea- $\mathrm{NH}_{4} \mathrm{NO}_{3}$, or granular urea, at $50 \mathrm{~kg} \mathrm{~N} \mathrm{ha}^{-1}$ ) applied to tall fescue plots. Huckaby Knight et al. (2012) reported significantly lower volatilization of coated urea-N than uncoated urea from warm-season turfgrass (e.g., 3.6-4.4 vs. 11.7-17.9\%) fertilized at $146 \mathrm{~kg} \mathrm{~N} \mathrm{ha}^{-1}$.

Surprisingly, leaching IN losses only constituted $2 \%$ of annual $\mathrm{N}$ inputs in Typical. $\mathrm{N}$ leaching could be as high as $41 \%$ of applied $\mathrm{N}$ from agriculture fields (Mosier et al. 2002) and up to $30 \%$ from turfgrass (Barton and Colmer 2006). Previous studies have shown low leaching inorganic $\mathrm{N}$ losses from relatively young turf lawns even under high fertilization rates (Barton and Colmer 2006), e.g., $1.1 \%$ from a 1-year-old couch grass lawn $\left(\mathrm{C}_{4}\right)$ fertilized at $195 \mathrm{~kg} \mathrm{~N} \mathrm{ha}^{-1}$ year $^{-1}$ (Pathan et al. 2007) and $1.5 \%$ from a 3 -year-old mixed cool-season turf fertilized at $147 \mathrm{~kg} \mathrm{~N} \mathrm{ha}^{-1}$ year $^{-1}$ (Guillard and Kopp 2004). Much higher leaching IN loss was reported from over-fertilized mature turfgrass. Frank et al. (2006) conducted a two-year study in a 10-year-old Kentucky bluegrass turf and found 10 times higher leaching of ${ }^{15} \mathrm{~N}$-labeled fertilizer $\mathrm{N}$ from the high- $\mathrm{N}$ treatment $\left(245 \mathrm{~kg} \mathrm{~N}^{-1}\right.$ year $^{-1}, \sim 10 \%$ loss) than the low- $\mathrm{N}$ treatment $\left(98 \mathrm{~kg} \mathrm{~N}^{-1}\right.$ year $^{-1}$, $\sim 1 \%$ loss). The lawns in our study are relatively young 
(4-5 years old); the inorganic $\mathrm{N}$ concentrations in soil solution at $40 \mathrm{~cm}$ were constantly low except for a short peak following fertilization, suggesting effective controls on soil inorganic $\mathrm{N}$ by plant uptake and microbial immobilization. There is uncertainty in our estimated volume of drainage; however, at such low inorganic $\mathrm{N}$ concentrations, even if we assume that all irrigation water was lost in drainage (i.e., zero runoff and ET), the leaching inorganic $\mathrm{N}$ estimates would be no more than $4 \%$ of the $\mathrm{N}$ inputs in Typical and 1 or $2 \%$ of $\mathrm{N}$ inputs in Low Input and Low Impact.

The largest uncertainty in our leaching $\mathrm{N}$ loss estimate is the absence of dissolved organic nitrogen (DON) measurements, which have been reported to constitute up to 10-70\% (average at $40 \%$ ) of total leaching $\mathrm{N}$ losses within 55 days (Pare et al. 2008) and up to $50 \%$ in 2 years (Barton et al. 2009) from lawns fertilized at various rates. Pare et al. (2008) showed in a ${ }^{15} \mathrm{~N}$-tracer experiment that most DON in leachate was from soil instead of labeled fertilizer, while Barton et al. (2009) reported that the majority of DON leaching occurred during the first year of lawn establishment from sod instead of fertilizer. Therefore, at relatively low $\mathrm{N}$ fertilization rates, it is possible for young lawns established from sod, or lawns with high soil organic matter (SOM) in general, to have relatively high DON leaching losses. Many current studies of leaching $\mathrm{N}$ from lawns focused on inorganic $\mathrm{N}$, especially $\mathrm{NO}_{3}{ }^{-}-\mathrm{N}$, since $\mathrm{NO}_{3}{ }^{-}-\mathrm{N}$ is highly leachable and may be a threat to public health in groundwater (e.g., Amador et al. 2007; Bowman et al. 2006; Devitt et al. 2008b; Frank et al. 2006; Groffman et al. 2009b; Guillard and Kopp 2004; Wu et al. 2007). Future studies may verify the magnitudes of DON leaching from lawns under different management regimes.

Due to the distinct seasonal pattern of plant $\mathrm{N}$ uptake, the timing of fertilization is also an important factor that affects soil $\mathrm{N}$ losses. The highest denitrification rates occurred in the cool season of March for Low Input $\left(\mathrm{C}_{4}\right)$ but in summer for Typical $\left(\mathrm{C}_{3}\right)$, during which the lawns were relatively inactive and therefore presumably in less competition for $\mathrm{N}$ with soil microbes. Similarly, Horgan et al. (2002a) reported denitrification fluxes from a $\mathrm{C}_{3}$ lawn as about 17-26\% in summer versus $4-6 \%$ in spring of ${ }^{15} \mathrm{~N}$-labeled fertilizer $\mathrm{N}$. These results show how $\mathrm{N}$ losses and emissions of pollutants such as $\mathrm{N}_{2} \mathrm{O}$, and $\mathrm{NO}_{3}{ }^{-}-\mathrm{N}$ from lawn soils are enhanced when fertilizer is applied during the seasons when plant growth is less active.
$\mathrm{N}$ retention in soil and implications for $\mathrm{N}$ saturation

Based on the SOC accumulation rate in 0-20 cm depth soil of ornamental lawns in parks in Irvine, California (0.14 kg OC m ${ }^{-2}$ year $^{-1}$, Townsend-Small and Czimczik 2010) and the range of lawn soil C:N ratios in our study (15.2-18.0), the soil organic $\mathrm{N}$ accumulation rates in our lawns could be as high as 80-90 kg N ha ${ }^{-1}$ year $^{-1}$. Raciti et al. (2011a) investigated 32 residential lawns in Baltimore, Maryland and found potential soil $\mathrm{C}$ and $\mathrm{N}$ accumulation rates as $0.082 \mathrm{~kg} \mathrm{C} \mathrm{m}^{-2}$ year $^{-1}$ and $83 \mathrm{~kg} \mathrm{~N} \mathrm{ha}^{-1}$ year $^{-1}$. Selhorst and Lal (2013) reported soil $\mathrm{C}$ sequestration rates from 0.09 to $0.54 \mathrm{~kg} \mathrm{C} \mathrm{m}^{-2}$ year $^{-1}$ from home lawns in 16 sites across the U.S.

Soil N immobilization (biotic and abiotic) may be an important mechanism for $\mathrm{N}$ retention in soil, especially at the 30 day scale following fertilization. In the 30 day soil incubation with simulated fertilizer application, we found similar, high net $\mathrm{N}$ immobilization rates of $25.2 \pm 5.4,16.4 \pm 6.8$, and $16.3 \pm 10.3 \mathrm{~kg} \mathrm{~N} \mathrm{ha}^{-1}$ month $^{-1}$ for Typical, Low Input, and Low Impact, respectively, accounting for approximately $30-65 \%$ of $\mathrm{N}$ inputs. This suggests "luxury uptake" and storage of $\mathrm{N}$ by the microbial community when $\mathrm{N}$ was supplied in large amount (Fog 1988), or rapid abiotic immobilization of $\mathrm{N}$ into mineral soil, which has been reported to occur within minutes to a few hours in many ${ }^{15} \mathrm{~N}$ tracer studies (e.g., Aber et al. 1998; Dail et al. 2001; Davidson et al. 2003; Zhu and Wang 2011). An uncertainty in our estimate is the lack of seasonality: the soils were only sampled in spring and incubated at constant temperature and soil moisture. We applied this single value over the study period (Fig. 3). However, soil net $\mathrm{N}$ immobilization potential may have shown seasonal variations associated with climate, microbial activities, and plant uptake (Horgan et al. 2002a; Wherley et al. 2009; Yao et al. 2011). This may explain why the total $\mathrm{N}$ outputs plus estimated immobilization in soil exceeded the total $\mathrm{N}$ inputs in Low Input in May 2010 (Fig. 3). At the annual scale, the estimates of $\mathrm{N}$ retention in soil through biotic and abiotic immobilization were relatively high: 87, 57, and $29 \mathrm{~kg} \mathrm{~N} \mathrm{ha}^{-1}$ year $^{-1}$ in Typical, Low Input, and Low Impact, respectively, which is fairly proportional to their fertilization rates (Table 1b). The three lawns might have similarly retained as much as $40 \%$ of the fertilizer $\mathrm{N}$ in soil through immobilization annually, even without clipping return, which is similar 
to the findings of previous ${ }^{15} \mathrm{~N}$ studies that showed that mineral soil is the long-term sink for fertilizer $\mathrm{N}$ in lawns (Frank et al. 2008; Raciti et al. 2008, 2011b).

Other mechanisms might also have played a role in soil $\mathrm{N}$ retention of urban lawns in general, such as the accumulation of plant litter, the variation in root biomass $\mathrm{N}$, and $\mathrm{N}$ assimilated into thatch. However, these factors likely played less important roles in our study. For example, the accumulation of plant litter mainly depends on the rates of litter production and microbial decomposition, both of which may be affected by lawn species and management regimes. Kopp and Guillard (2004) showed rapid C and N losses from clipping decomposition of about $90 \%$ within 16 weeks; however, at our sites, clippings were removed. The Low Input lawn may have relatively high accumulation rates of plant litter and associated organic $\mathrm{N}$ in soil due to the high biomass productivity. We did not directly measure the litter decomposition rates, but the Low Input lawn had the highest foliar C:N ratio, root $\mathrm{C}: \mathrm{N}$ ratio (Typical: $37.0 \pm 2.3$, Low Input: $52.0 \pm 3.2$, Low Impact: $40.3 \pm 5.9, P<0.001)$, and the lowest irrigation rates, all of which may negatively impact litter decomposition. Also, we did not see any significant monthly or annual variation in root biomass $\mathrm{N}$, and there was no visible thatch layer, probably due to consistent removal of clippings.

Qian and Follett (2012) hypothesized that high rates of soil $\mathrm{N}$ accumulation are driven by rapid $\mathrm{C}$ sequestration in young turf ecosystems; however, once soil C accumulation reaches a steady state, continuous $\mathrm{N}$ fertilization may lead to increasing gaseous and aqueous $\mathrm{N}$ losses as initial signs of $\mathrm{N}$ saturation. Such $\mathrm{N}$ losses may increase in magnitude over time and eventually approach or even exceed $\mathrm{N}$ inputs as the final stage of $\mathrm{N}$ saturation (Aber et al. 1989; Agren and Bosatta 1988). The rate and duration of $\mathrm{N}$ accumulation in lawn soils are tightly coupled to those of soil $\mathrm{C}$ accumulation and are also affected by the temporal variation in soil C:N ratio, which represents the net balance between soil immobilization and mineralization over time. With simulations of lawn dynamics generated from the CENTURY model, Qian and Follett (2002) and Bandaranayake et al. (2003) similarly showed that SOC accumulation in urban lawns could continue for up to $30-45$ years, with a rapid linear increase in the first 25-30 years at an approximate rate of 0.9-1.2 $\mathrm{Mg} \mathrm{C} \mathrm{ha}{ }^{-1}$ year $^{-1}$ (or $0.09-0.12 \mathrm{~kg} \mathrm{C} \mathrm{m}^{-2}$ year $^{-1}$ ). Field observations supported this hypothesis. Townsend-
Small and Czimczik (2010) investigated 0-20 cm soils of ornamental lawns $(2,8,27$, and 33 year) in parks in Irvine, California, and showed that SOC increased linearly within 35 years at an approximate rate of $0.14 \mathrm{~kg} \mathrm{OC} \mathrm{m}^{-2}$ year $^{-1}$. Shi et al. (2006) reported linear increases in both soil $\mathrm{C}$ and $\mathrm{N}$ densities in a chronosequence of a turf system $(1,6,23$, and 95 year golf courses) in North Carolina, which suggests that SOC accumulation may even continue after 45 years and maintain a strong soil sink for $\mathrm{N}$.

This study was intended to measure the consequences of "typical", i.e., high water and $\mathrm{N}$ input landscape designs, as well as designs intended to reduce the environmental impacts of lawns. Our results generally support the effectiveness of the alternative designs at reducing water use and $\mathrm{N}$ outputs. However, urban landscape design and management vary greatly among parcels, neighborhoods, and municipalities, and $\mathrm{N}$ budgets should be constructed in additional landscapes to develop a more general framework for $\mathrm{N}$ processes in urban residences. In addition, there are potentially useful management practices that were not explicitly tested here. Currently, clippings are commonly disposed of as waste. However,to facilitate accumulation of organic matter in lawn soils and reduce the need for fertilization, leaving clippings on site during the growing season (i.e., clipping return, or "grasscycling"), is usually recommended (Harivandi and Gibeault 1999; Hartin and Harivandi 2001; Milesi et al. 2005). Qian et al. (2003) showed with a CENTURY model simulation that clipping return may increase soil sequestration of $\mathrm{C}$ and $\mathrm{N}$ by $11-59$ and $12-78 \%$, with greater improvements under lower rather than higher fertilization rates (75 vs. $150 \mathrm{~kg} \mathrm{~N} \mathrm{ha}^{-1}$ year $^{-1}$ ); meanwhile, this practice may reduce the $\mathrm{N}$ requirement of lawns from 25-60\% depending on lawn age. Other studies also showed that clipping return, along with appropriate mowing frequencies, may reduce the need for fertilization (Heckman et al. 2008; Kopp and Guillard 2002), preserve soil moisture (Harivandi and Gibeault 1999; Hartin and Harivandi 2001), and improve plant N uptake (Kopp and Guillard 2002); however, it might also potentially increase leaching loss of $\mathrm{NO}_{3}{ }^{-}$, especially when fertilization was not reduced or irrigation was excessive (Kopp and Guillard 2005). These practices should be further tested in an ecosystem $\mathrm{N}$ budget framework. 


\section{Conclusions}

In constructing $\mathrm{N}$ budgets described here, we accounted for virtually all of the measured $\mathrm{N}$ inputs and outputs, albeit with a high degree of uncertainty in some estimated pathways of $\mathrm{N}$ loss. We attempted to sample a range of landscape designs, from a design that utilizes intensive $\mathrm{N}$ and water inputs to two alternative designs intended to maintain lawns with lower to minimal inputs. Overall, our results showed that the Low Input lawn was relatively efficient in assimilating $\mathrm{N}$ inputs in plant biomass and soil stocks with low water and $\mathrm{N}$ costs, which may make this design a good choice for semiarid urban ecosystems like those in the Los Angeles Basin, where both water use and $\mathrm{N}$ pollution is a concern. Additional adjustments to the management practices in this design such as reducing fertilization rates during the dormant seasons (March for seashore paspalum) or according to temperature may further increase the efficiency of $\mathrm{N}$ fertilization and reduce denitrification losses.

Our study also showed that all three lawns, despite receiving different rates of $\mathrm{N}$ and water inputs, appear to be accumulating $\mathrm{C}$ and $\mathrm{N}$ rapidly in the soil, especially during the fertilization periods, with surprisingly small $\mathrm{N}$ losses. Management of lawn species adapted to the local climate type (e.g., a warm-season $\mathrm{C}_{4}$ species for a semi-arid ecosystem) may maximize the recreational and aesthetic benefits of lawns and minimize the potential environmental impacts. Clipping return, reduced fertilization rates, and targeting fertilization during the active growing season are all recommended management strategies, especially as lawns age, not only to increase soil $\mathrm{C}$ accumulation but also to reduce consumption of water and fertilizer as well as potential detrimental environmental impacts of soil $\mathrm{N}$ saturation.

Acknowledgments We thank Tammy Majcherek, Neeta Bijoor, Amy Townsend-Small, and Claudia Czimczik for site information and field assistance. We thank Dachun Zhang for laboratory instructions and assistance. For the measurements of atmospheric $\mathrm{N}$ deposition, we thank Mark Fenn and Andrzej Bytnerowicz for instructions and access to their lab facilities and Christopher Ross for his kind help in instrument installation and sample analysis. This study was funded by U.S. Department of Agriculture grant 2006-04686, UCI Urban Water Research Center, and National Science Foundation grant DEB 0919381.
Open Access This article is distributed under the terms of the Creative Commons Attribution License which permits any use, distribution, and reproduction in any medium, provided the original author(s) and the source are credited.

\section{References}

Aber JD, Nadelhoffer K, Steudler P, Melillo J (1989) Nitrogen saturation in northern forest ecosystems. Bioscience 39:378-386

Aber JD, Ollinger S, Driscoll C (1998) Modeling nitrogen saturation in forest ecosystems in response to land use and atmospheric deposition. Ecol Model 101:61-78

Agren GI, Bosatta E (1988) Nitrogen saturation of terrestrial ecosystems. Environ Pollut 54:185-197

Amador JA, Hull RJ, Patenaude EL, Bushoven JT, Gorres JH (2007) Potential nitrate leaching under common landscaping plants. Water Air Soil Pollut 185:323-333

Bandaranayake W, Qian YL, Parton WJ, Ojima DS, Follett RF (2003) Estimation of soil organic carbon changes in turfgrass systems using the CENTURY model. Agron J 95:558-563

Barton L, Colmer TD (2006) Irrigation and fertiliser strategies for minimizing nitrogen leaching from turfgrass. Agric Water Manag 80:160-175

Barton L, McLay CDA, Schipper LA, Smith CT (1999) Annual denitrification rates in agricultural and forest soils: a review. Aust J Soil Res 37:1073-1093

Barton L, Wan GGY, Buck RP, Colmer TD (2009) Does N fertiliser regime influence $\mathrm{N}$ leaching and quality of different-aged turfgrass (Pennisetum clandestinum) stands? Plant Soil 316:81-96

Baumgartner M, Conrad R (1992) Effects of soil variables and season on the production and consumption of nitric oxide in oxic soils. Biol Fertil Soils 14:166-174

Bijoor NS (2008) Effects of temperature and fertilization on nitrogen cycling and community composition of an urban lawn. Glob Change Biol 14:2119-2131

Bouwman AF, Boumans LJM, Batjes NH (2002) Emissions of $\mathrm{N}_{2} \mathrm{O}$ and $\mathrm{NO}$ from fertilized fields: summary of available measurement data. Glob Biogeochem Cycles. doi:10.1029/ 2001GB001811

Bowman DC, Cherney CT, Rufty TW Jr (2002) Fate and transport of nitrogen applied to six warm-season turfgrasses. Crop Sci 42:833-841

Bowman DC, Devitt DA, Miller WW (2006) The effect of moderate salinity on nitrate leaching from Bermudagrass turf: a lysimeter study. Water Air Soil Pollut 175:49-60

Bytnerowicz A, Fenn ME (1996) Nitrogen deposition in California forests: a review. Environ Pollut 92:127-146

Clayton H, McTaggart IP, Parker J, Swan L, Smith KA (1997) Nitrous oxide emissions from fertilised grassland: a 2-year study of the effects of $\mathrm{N}$ fertiliser form and environmental conditions. Biol Fertil Soils 25:252-260

Crush JR, Waller JE, Care DA (2005) Root distribution and nitrate interception in eleven temperate forage grasses. Grass Forage Sci 60:385-392 
Dail DB, Davidson EA, Chorover J (2001) Rapid abiotic transformation of nitrate in an acid forest soil. Biogeochemistry 54:131-146

Davidson EA (1991) Fluxes of nitrous oxide and nitric oxide from terrestrial ecosystems. In: Rogers JW, Whitman WB (eds) Microbial production and consumption of greenhouse Gases: Methane, nitrogen oxides and halomethane. American Society of Microbiology, Washington, D.C., pp 219-235

Davidson EA, Chorover J, Dail DB (2003) A mechanism of abiotic immobilization of nitrate in forest ecosystems: the ferrous wheel hypothesis. Glob Change Biol 9:228-236

Davis SL, Dukes MD, Miller GL (2009) Landscape irrigation by evapotranspiration-based irrigation controllers under dry conditions in Southwest Florida. Agric Water Manag 96:1828-1836

Devitt DA, Carstensen K, Morris RL (2008a) Residential water savings associated with satellite-based ET irrigation controllers. J Irrigation Drainage Eng 134:74-82

Devitt DA, Wright L, Bowman DC, Morris RL, Lockett M (2008b) Nitrate-N concentrations in the soil solution below reuse irrigated golf course fairways. HortScience 43:2196-2202

Doane TA, Horwath WR (2003) Spectrophotometric determination of nitrate with a single reagent. Anal Lett 36: $2713-2722$

Drury CF, Oloya TO, Tan CS, vanLuyk CL, McKenney DJ, Gregorich EG (1997) Long-term effects of fertilization and rotation on denitrification and soil carbon. Soil Sci Soc Am J 62:1572-1579

Drury CF, Myrold DD, Beauchamp EG, Reynolds WD (2008) Denitrification techniques for soils. In: Carter MF, Gregorich EG (eds) Soil sampling and methods of analysis, 2nd edn. CRC Press, Bota Raton, pp 471-494

Eichner MJ (1990) Nitrous oxide emissions from fertilized soils: summary of available data. J Environ Qual 19:272-280

Engelsjord ME, Branham BE, Horgan BP (2004) The fate of nitrogen-15 ammonium sulfate applied to Kentucky bluegrass and perennial ryegrass turfs. Crop Sci 44:1341-1347

Fenn ME, Poth MA (2004) Monitoring nitrogen deposition in throughfall using ion exchange resin columns: a field test in the San Bernardino Mountains. J Environ Qual 33:2007-2014

Fenn ME, Haeuber R, Tonnesen GS, Baron JS, GrossmanClarke S, Hope D, Jaffe DA, Geiser L, Rueth HM, Sickman JO (2003) Nitrogen emissions, deposition, and monitoring in the Western United States. Bioscience 53:391-403

Fenn ME, Geiser L, Bachman R, Blubaugh TJ, Bytnerowicz A (2006) Atmospheric deposition inputs and effects on lichen chemistry and indicator species in the Columbia River Gorge, USA. Environ Pollut 146:77-91

Fenn ME, Allen EB, Weiss SB, Jovan S, Geiser L, Tonnesen GS, Johnson RF, Rao LE, Gimeno BS, Yuan F, Meixner T, Bytnerowicz A (2010) Nitrogen critical loads and management alternatives for $\mathrm{N}$-impacted ecosystems in California. J Environ Manag 91:2404-2423

Firestone MK, Davison EA (1989) Microbiological basis of NO and $\mathrm{N}_{2} \mathrm{O}$ production and consumption in soil. In: Andreae MO, Schimel DS (eds) Exchange of trace gases between terrestrial ecosystems and the atmosphere. Wiley, New York, pp 7-21
Fog K (1988) The effect of added nitrogen on the rate of decomposition of organic matter. Biol Rev 63:433-462

Frank KW, O'Reilly KM, Crum JR, Calhoun RN (2006) The fate of nitrogen applied to a mature Kentucky Bluegrass turf. Crop Sci 46:209-215

Frankenberger WT, Tabatabai MA (1982) Amidase and urease activities in plants. Plant Soil 64:53-166

Galloway JN, Aber JD, Erisman JW, Seitzinger SP, Howarth RW, Cowling EB, Cosby BJ (2003) The nitrogen cascade. Bioscience 53:341-356

Gleick PH, Haasz D, Henges-Jeck C, Srinivasan V, Wolff G, Kao Cushing K, Mann A (2003) Waste not, want not: the potential for urban water conservation in California. Pacific Institute, Oakland

Groffman PM, Butterbach-Bahl K, Fulweiler RW, Gold AJ, Morse JL, Stander EK, Tague C, Tonitto C, Vidon P (2009a) Challenges to incorporating spatially and temporally explicit phenomena (hotspots and hot moments) in denitrifcation models. Biogeochemistry 93:49-77

Groffman PM, Williams CO, Pouyat RV, Band LE, Yesilonis ID (2009b) Nitrate leaching and nitrous oxide flux in urban forests and grasslands. J Environ Qual 38:1848-1860

Gu C, Maggi F, Riley WJ, Hornberger GM, Xu T, Oldenburg CM, Spycher N, Miller NL, Venterea RT, Steefel G (2009) Aqueous and gaseous nitrogen losses induced by fertilizer application. J Geophys Res. doi:10.1029/2008J G000788

Guillard K, Kopp KL (2004) Nitrogen fertilizer form and associated nitrate leaching from cool-season lawn turf. J Environ Qual 33:1822-1827

Hall SJ, Huber D, Grimm NB (2008) Soil $\mathrm{N}_{2} \mathrm{O}$ and NO emissions from an arid, urban ecosystem. J Geophys Res. doi:10.1029/2007JG000523

Harivandi A, Gibeault VA (1999) Mowing your lawn and "Grasscycling". University of California, Oakland

Hartin JS, Harivandi A (2001) Reusing turfgrass clippings to improve turfgrass health and performance in central and northern California. California Integrated Waste Management Board, Publ. 443-01-021

Heckman J, Liu H, Hill W, DeMila M, Anastasia W (2008) Kentucky bluegrass responses to mowing practice and nitrogen fertility management. J Sustain Agric 15:25-33

Henry JM, Gibeault VS, Lazaneo VF (2002) Practical lawn fertilization. University of California, Oakland

Horgan BP, Branham BE, Mulvaney RL (2002a) Mass balance of ${ }^{15} \mathrm{~N}$ applied to Kentucky Bluegrass including direct measurement of denitrification. Crop Sci 42:1595-1601

Horgan BP, Branham BE, Mulvaney RL (2002b) Direct measurement of denitrification using $15 \mathrm{~N}$-labeled fertilizer applied to turfgrass. Crop Sci 42:1602-1610

Huang B, Duncan RR, Carrow RN (1997) Drought-resistance mechanisms of seven warm-season turfgrasses under surface soil drying: II. Root aspects. Crop Sci 37:1863-1869

Huckaby Knight EC, Wooda CW, Guertal EA (2012) Nitrogen source effects on ammonia volatilization from warm-season sod. Crop Sci 52:1379-1384. doi:10.2135/cropsci2011. 04.0198

Huh KY, Deurer M, Sivakumaran S, McAuliffe K, Bolan NS (2008) Carbon sequestration in urban landscapes: the 
example of a turfgrass system in New Zealand. Aust J Soil Res 46:610-616

Hutchinson GL, Davidson EA (1993) Processes for production and consumption of gaseous nitrogen oxides in soil. In: Harper LA, Mosier AR, Duxbury M, Rolston DE (eds) Agricultural ecosystem effects on trace gases and global climate change. American Society of Agronomy, Madison, pp 79-93

Intergovernmental Panel on Climate Change (2001) Third assessment report. Working group I. Cambridge University Press, New York

Jiao Y, Hendershot YH, Whalen JK (2004) Agricultural practices influence dissolved nutrients leaching through intact soil cores. Soil Sci Soc Am J 68:2058-2068

Jungkunst HF, Freibauer A, Neufeldt H, Bareth G (2006) Nitrous oxide emissions from agricultural land use in Germany-a synthesis of available annual field data. J Plant Nutr Soil Sci 169:341-351

Kaye JP, Burke IC, Mosier AR, Guerschman JP (2004) Methane and nitrous oxide fluxes from urban soils to the atmosphere. Ecol Appl 14:975-981

Kopp K, Guillard K (2002) Clipping management and nitrogen fertilization of turfgrass: growth, nitrogen utilization, and quality. Crop Sci 42:1225-1231

Kopp K, Guillard K (2004) Decomposition and nitrogen release rates of turfgrass clippings. In: Proceedings of the 4th international crop science congress. 26 September-1 October, 2004. Brisbane, QLD, Australia

Kopp K, Guillard K (2005) Clipping contributions to nitrate leaching from creeping bentgrass under varying irrigation and $\mathrm{N}$ rates. Int Turfgrass Soc Res J 10:80-85

Law NL, Band LE, Grove JM (2004) Nitrogen input from residential lawn care practices in suburban watersheds in Baltimore County, MD. J Environ Plan Manag 47:737-755

Long SP (1999) Environmental responses. In: Sage RF, Monson $\mathrm{RK}$ (eds) $\mathrm{C}_{4}$ plant biology. Academic Press, San Diego, pp 215-250

McCready MS, Dukes MD, Miller GL (2009) Water conservation potential of smart irrigation controllers on St. Augustine grass. Agric Water Manag 96:1623-1632

Milesi C, Running SW, Elvidge CD, Dietz JB (2005) Mapping and modeling the biogeochemical cycling of turf grasses in the United States. Environ Manag 36:426-438

Morton TG, Gold AJ, Sullivan WM (1988) Influence of overwatering and fertilization on nitrogen losses from home lawns. J Environ Qual 17:124-140

Mosier AR, Doran JW, Freney JR (2002) Managing soil denitrification. J Soil Water Conserv 57:505-512

Pare K, Chantigny MH, Carey K, Dionne J (2008) Leaching of mineral and organic nitrogen from putting green profiles supporting various turfgrasses. Crop Sci 48:2010-2016

Parton WJ, Jolland EA, Del Grosso SJ, Hartman MD, Martin RE, Mosier AR, Ojima DS, Schimel DS (2001) Generalized model for $\mathrm{NO}_{\mathrm{x}}$ and $\mathrm{N}_{2} \mathrm{O}$ emissions from soils. J Geophys Res 106:17403-17419

Pataki DE, Alig RJ, Fung AS, Golubiewski NE, Kennedy CA, McPherson EG, Nowak DJ, Pouyat RV, Romero Lankao P (2006) Urban ecosystems and the North American carbon cycle. Glob Change Biol 12:2092-2101

Pathan SM, Barton L, Colmer TD (2007) Evaluation of a soil moisture sensor to reduce water and nutrient leaching in turfgrass (Cynodon dactylon cv. Wintergreen). Aust J Exp Agric 47:215-222

Petrovic AM (1990) The fate of nitrogenous fertilizers applied to turfgrass. J Environ Qual 19:1-14

Pouyat RV, Russell-Anelli J, Yesilonis ID, Groffman PM (2003) Soil carbon in urban forest ecosystems. In: Heath LS, Birdsey RA, Lal R, Kimble JM (eds) The potential of U.S. forest soils to sequester carbon and mitigate the greenhouse effect. CRC, Boca Raton

Pouyat RV, Yesilonis ID, Nowak DJ (2006) Carbon storage by urban soils in the USA. J Environ Qual 35:1566-1575

Pruitt WO, Doorenbos J (1977) Empirical calibration, a requisite for evapotranspiration formulae based on daily or longer mean climatic data. In: International round table conference on evapotranspiration, International Committee on Irrigation and Drainage, Budapest, Hungary

Qian YL, Follett RF (2002) Assessing soil carbon sequestration in turfgrass systems using long-term soil testing data. Agron J 94:930-935

Qian YL, Follett RF (2012) Carbon dynamics and sequestration in urban turfgrass ecosystems. In: Lai R, Augustin B (eds) Carbon sequestration in urban ecosystems. Springer, Amsterdam, pp 161-172

Qian Y, Bandaranayake W, Parton W, Mecham B, Harivandi M, Mosier A (2003) Long-term effects of clipping and nitrogen management in turfgrass on soil organic carbon and nitrogen dynamics: the CENTURY model simulation. J Environ Qual 32:1695-1700

Raciti SM, Groffman PM, Fahey TJ (2008) Nitrogen retention in urban lawns and forests. Ecol App 18:1615-1626

Raciti SM, Burgin AJ, Groffman PM, Lewis DN, Fahey TJ (2011a) Denitrification in suburban lawn soils. J Environ Qual 40:1932-1940

Raciti SM, Groffman PM, Jenkins JC, Pouyat RV, Fahey TJ, Pickett STA, Cadenasso ML (2011b) Accumulation of carbon and nitrogen in residential soils with different landuse histories. Ecosystems 14:287-297

Scanlon BR, Jolly I, Sophocleous M, Zhang L (2007) Global impacts of conversions from natural to agricultural ecosystems on water resources: quantity versus quality. Water Resour Res. doi:10.1029/2006WR005486

Schlesinger WH, Peterjohn WT (1991) Processes controlling ammonia volatilization from Chihuahuan Desert soils. Soil Biol Biochem 23:637-642

Selhorst A, Lal R (2013) Net carbon sequestration potential and emissions in home lawn turfgrasses of the United States. Environ Manag 51:198-208

Shi W, Yao H, Bowman D (2006) Soil microbial biomass, activity and nitrogen transformations in a turfgrass chronosequence. Soil Biol Biochem 38:311-319

Šimek M, Cooper JE, Picek T, Šantrůčková H (2000) Denitrification in arable soils in relation to their physico-chemical properties and fertilization practice. Soil Biol Biochem 32:101-110

Snyder R, Pruitt W (1985) Estimating reference evapotranspiration with hourly data, chapter VII, vol 1 . In: California irrigation management information system final report, land, air and water resources paper \#10013-A, University of California, Davis, CA, USA

Stehfest E, Bouwman L (2006) $\mathrm{N}_{2} \mathrm{O}$ and $\mathrm{NO}$ emission from agricultural fields and soils under natural vegetation: 
summarizing available measurement data and modeling of global annual emissions. Nutr Cycl Agroecosyst 74:207-228

Synder GH, Augustin BJ, Davidson JM (1984) Moisture sensorcontrolled irrigation for reducing $\mathrm{N}$ leaching in bermudagrass turf. Agron J 76:964-969

Torello WA, Wehner DJ, Turgeon AJ (1983) Ammonia volatilization from fertilized turfgrass stands. Agron J 75:454-456

Townsend-Small A, Czimczik CI (2010) Carbon sequestration and greenhouse gas emissions in urban turf. Geophys Res Lett. doi:10.1029/2009GL041675

Townsend-Small A, Pataki DE, Czimczik C, Tyler S (2011) Nitrous oxide emissions and isotopic composition in urban and agricultural systems in southern California. J Geophys Res 116:G01013. doi:101029/2010JG001494

Vaio N, Cabrera ML, Kissel DE, Rema JA, Newsome JF, Calvert VH II (2007) Ammonia volatilization from urea-based fertilizers applied to tall fescue pastures in Georgia, USA. Soil Sci Soc Am J 72:1665-1671

Virginia RA, Jarrell WM, Franco-Vizcaino E (1982) Direct measurement of denitrification in a Prosopis (Mesquite) dominated Sonoran Desert ecosystem. Oecologia 53:120-122

Wang W, Pataki DE (2012) Drivers of spatial variability in urban plant and soil isotopic composition in the Los Angeles basin. Plant Soil 350:323-338

Wang W, Zhu WX (2012) Soil retention of ${ }^{15} \mathrm{~N}$ in a simulated $\mathrm{N}$ deposition study: effects of live plant and soil organic matter content. Plant Soil 351:61-72
Weatherburn MW (1967) Phenol-hypochlorite reaction for determination of ammonia. Anal Chem 39:971-974

Wherley BG, Shi W, Bowman DC, Rufty TW (2009) Fate of ${ }^{15} \mathrm{~N}$-nitrate applied to a bermudagrass system: assimilation profiles in different seasons. Crop Sci 49:2291-2301

Williams PH, Jarvis SC, Dixon E (1998) Emission of nitric oxide and nitrous oxide from soil under field and laboratory conditions. Soil Biol Biochem 30:1885-1893

Wu L, Green R, Yates MV, Pacheco P, Klein G (2007) Nitrate leaching in overseeded Bermudagrass fairways. Crop Sci 47:2521-2528

Yao H, Bowman D, Shi W (2011) Seasonal variations of soil microbial biomass and activity in warm- and cool-season turfgrass systems. Soil Biol Biochem 43:1536-1543

Youngner VB, Marsh AW, Strohman RA, Gibeault VA, Spaulding S (1981) Water use and turf quality of warmseason and cool-season turfgrasses. In: Sheard R (ed) Proceedings of the 4th international turfgrass research conference, Guelph, ON, Canada, International Turfgrass Society and University of Guelph, ON, Canada, pp 257-259, 19-23 Jul 1981

Zhu WX, Carreiro MM (1999) Chemoautotrophic nitrification in acidic forest soils along an urban-to-rural transect. Soil Biol Biochem 31:1091-1100

Zhu WX, Wang W (2011) Does soil organic matter variation affect the retention of ${ }^{15} \mathrm{NH}_{4}{ }^{+}$and ${ }^{15} \mathrm{NO}_{3}{ }^{-}$in forest ecosystems? Forest Ecol Manag 261:675-682 